\title{
Morphological and molecular diagnostic species characters of Staurozoa (Cnidaria) collected on the coast of Helgoland (German Bight, North Sea)
}

\author{
Sabine Holst ${ }^{1}\left[\right.$ ] Anneke Heins $^{2} \cdot$ Silke Laakmann $^{3,4}$
}

Received: 14 November 2017 / Revised: 25 January 2019 / Accepted: 17 February 2019

(C) Senckenberg Gesellschaft für Naturforschung 2019

\begin{abstract}
Scientific knowledge and records on staurozoans are limited probably because of their inconspicuous life habit and the small number of specialists for this taxon. To increase the awareness for Staurozoa, we identified morphological and molecular features of the three staurozoan species Haliclystus tenuis Kishinouye, 1910, Haliclystus auricula Clark, 1863, and Craterolophus convolvulus (Johnston, 1835) collected on the coast of the island Helgoland to evaluate their suitability as diagnostic characters. Useful macromorphological diagnostic features were the patterns of white spots of nematocysts and internal arm structures, whereas tentacle and gonad follicle numbers showed high intraspecific variations. Morphometric measurements on photographs of living specimens provided reliable data for interspecific comparisons. Comprehensive nematocyst analyses revealed interspecific shape differences of isorhizas and three types of rhopaloids, indicating that the staurozoan cnidome is more diverse than previously assumed. However, the taxonomic value of nematocyst analyses in Staurozoa remains unclear because comprehensive data is still lacking for most species. Comparative molecular genetic sequence analyses of mitochondrial $16 \mathrm{~S}$ and cytochrome $\mathrm{c}$ oxidase subunit I (COI) and nuclear 18S ribosomal DNA identified the three species and confirmed their morphological identification. In comparison to published data, our analyses indicate similarities between H. auricula and Haliclystus antarcticus Pfeffer, 1889. Proteomic fingerprinting by matrix-assisted laser desorption/ionization time-of-flight mass spectrometry (MALDITOF MS) differentiated all three species, suggesting that this technique could provide an alternative rapid identification method for staurozoans.
\end{abstract}

Keywords Stauromedusae $\cdot$ Integrative taxonomy $\cdot$ Species identification $\cdot$ Nematocysts $\cdot$ Molecular genetics $\cdot$ Proteomic fingerprinting

Communicated by S. Piraino

Electronic supplementary material The online version of this article (https://doi.org/10.1007/s12526-019-00943-1) contains supplementary material, which is available to authorized users.

Sabine Holst

sholst@senckenberg.de

1 German Center for Marine Biodiversity Research, Senckenberg am Meer, Martin-Luther-King-Platz 3, 20146 Hamburg, Germany

2 Research Group Animal Biodiversity and Evolutionary Biology, Institute for Biology and Environmental Sciences, Carl von Ossietzky University of Oldenburg, Carl-von-Ossietzky-Straße 9-11, 26129 Oldenburg, Germany

3 German Center for Marine Biodiversity Research, Senckenberg am Meer, Suedstrand 44, 26382 Wilhelmshaven, Germany

4 Present address: Helmholtz Institute for Functional Marine Biodiversity at the University of Oldenburg (HIFMB), Ammerländer Heerstraße 231, 26129 Oldenburg, Germany

\section{Introduction}

The cnidarian taxon Staurozoa currently comprises around 50 species (Miranda et al. 2018). Many of the recorded staurozoan species live in the intertidal, often camouflaged by surrounding sea weed, but also deep-sea species are known (Miranda et al. 2018). The life cycle of staurozoans is particular among the Medusozoa because it does not include any planktonic stage (Miranda et al. 2012a). Instead, the creeping planula (Otto 1976) develops into a sessile polyp whose apical part metamorphoses into the medusa-like calyx of the adult staurozoan (Kikinger and Salvini-Plawen 1995). Many staurozoan species appear with short seasonal peak abundances whereas their life stages outside of these periods are inconspicuous (Corbin 1979; Miranda et al. 2012a). Their inconspicuous life habit, their particular life cycle, and the limited number of specialists for the group may be reasons 
for the limited records resulting in a probably underestimated biodiversity and species richness of Staurozoa (Miranda et al. 2017, 2018).

Species identification of Staurozoa by macromorphological features is challenging because of high intraspecific variations and interspecific overlaps, which often led to misidentifications and to confusion in taxonomy (e.g., Hirano 1986, 1997; Miranda et al. 2009). Nevertheless, morphological species identification is still mainly based on these variable macromorphological features, e.g., the shape and dimensions of body parts, numbers of tentacles and gonad vesicles, and patterns of white nematocyst spots (e.g., Miranda et al. 2009, 2017; Kahn et al. 2010). Investigations on internal structures of the arms confirm that this feature, established by Hirano (1997), is important for the species differentiation in the genus Haliclystus Clark, 1863 (Miranda et al. 2016a; Holst and Laakmann 2019). Recent histological studies reveal that internal morphological structures have a high scientific value for systematic and evolutionary studies on staurozoans (Miranda et al. 2013, 2016a, b) but the applicability of this technique is limited to single selected specimens because of the invasive and time-consuming nature of histological sectioning. The taxonomic value of cnidome analyses is considered to be low for staurozoans because the same two nematocyst types were described for several staurozoan species (Fautin 2009). A few studies document nematocysts of different sizes in different body parts, indicating the presence of more than two nematocyst types in staurozoan species (e.g., Gwilliam 1956; Larson 1980, 1988; Larson and Fautin 1989; Collins and Daly 2005; Miranda et al. 2009; Zagal et al. 2011). However, comprehensive data with many replicate measurements per nematocyst type in various body parts are lacking for most staurozoan species and may reveal overlooked species-specific differences as previously shown for scyphozoans (e.g., Östman and Hydman 1997; Holst et al. 2007; Heins et al. 2015).

In the last decade, molecular genetic data were used to differentiate and identify cnidarian species (e.g., Dawson 2005; Moura et al. 2008; Ortman et al. 2010; Laakmann and Holst 2014) or to identify and verify morphological diagnostic characters in integrative morphological and molecular studies (e.g., Holst and Laakmann 2014, 2019). Regarding Staurozoa, morphological taxonomic studies were supplemented by molecular genetic analyses, mainly to reveal their evolutionary relationships and their systematic classification within the Cnidaria (e.g., Collins and Daly 2005; Collins et al. 2006; Miranda et al. 2010, 2016b; Gomez Daglio and Dawson 2017). These studies not only elucidate the staurozoan phylogeny and species diversity but also allow comparative analyses and thus consecutive research on different staurozoan taxa because of the open-access provision of published molecular sequence data.

Next to molecular genetics, the proteome fingerprints were progressively tested, modified, and applied to differentiate metazoan species. An advantage of this molecular identification method compared to DNA sequence analysis is the comparably fast and inexpensive application with few preparation steps and few consumables, allowing a rapid species identification. A common proteomic fingerprinting method is the matrix-assisted laser desorption/ionization time-of-flight mass spectrometry (MALDI-TOF MS), known and well established to identify and distinguish species and strains of microorganisms (e.g., Fenselau and Demirev 2001; Wieser et al. 2012). This methodology already revealed species-specific proteome profiles and thus valid species clusters for diverse metazoan taxa such as fish (Mazzeo et al. 2008; Volta et al. 2012), arthropods (Riccardi et al. 2012; Salla and Murray 2013; Laakmann et al. 2013; Rothen et al. 2016; Bode et al. 2017; Kaiser et al. 2018), and insects (Feltens et al. 2010; Kaufmann et al. 2011) but was not yet tested for any cnidarian taxa.

Observations on the disappearance of Staurozoa from their habitats indicate that they may be sensitive to water pollution and other changes of environmental conditions (e.g., Mayer 1910; Berrill 1962; Miranda and Marques 2016). Promotion of the group, including increasing records and monitoring efforts, could support the conservation of staurozoan species (Miranda et al. 2018). Two of the three staurozoan species collected on Helgoland for present investigations, Haliclystus auricula Clark, 1863 and Craterolophus convolvulus (Johnston, 1835), were previously reported for Helgoland in the last decades (Boos et al. 2004; Reichert and Buchholz 2006; Zettler et al. 2018). The specimens of Haliclystus tenuis Kishinouye 1910, collected on Helgoland in 2010, represent the first record of the species in Atlantic waters (Holst and Laakmann 2019). To increase the awareness for Staurozoa in future studies and monitoring programs, we evaluated the utility of morphological and molecular diagnostic features for species identification on the example of three staurozoan species collected on Helgoland. Our studies focused on (1) intra- and interspecific variations of macromorphological features described by previous authors, (2) comprehensive nematocyst analyses comprising high replicate numbers and various body regions, (3) DNA sequence analyses of mitochondrial (16S, cytochrome c oxidase subunit I (COI)) and nuclear (18S ribosomal DNA (rDNA)) gene fragments for species discrimination and comparative analyses with the published staurozoan sequence data, and (4) the evaluation of the applicability of proteomic fingerprinting for staurozoan species discrimination.

\section{Material and methods}

\section{Collection and macromorphological investigations}

Staurozoans were collected on the coast of the island Helgoland (see Table 1 for coordinates). On each sampling day, the sampling site was searched for staurozoans for about 


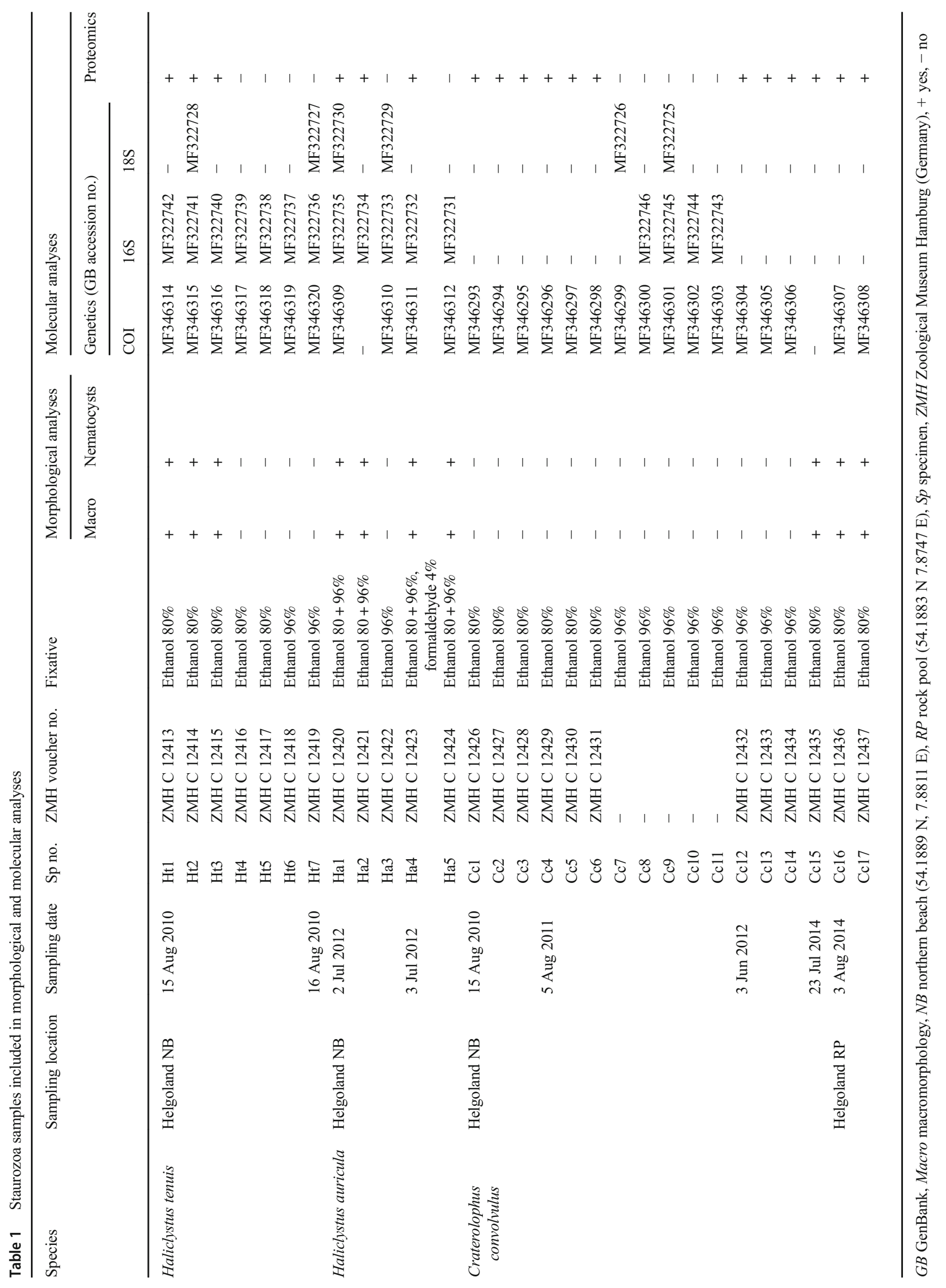


$1.5 \mathrm{~h}$ before and $1.5 \mathrm{~h}$ after low tide in the ankle-deep to kneedeep water at Helgoland's northern beach or in pools of the nearby rocky intertidal in summers 2010, 2011, 2012, and 2014 (Table 1, Fig. 1a, b). Collected specimens, attached to pieces of colonized macroalgae, were transported to the laboratories of the Biological Institute Helgoland (BAH) of the Alfred Wegener Institute, Helmholtz Centre for Polar and Marine Research in seawater-filled containers. Photographs on living specimens in lateral view (Fig. 1c) were used for measurements on (1) stalk length from the junction to the pedal disc to the junction of the dilating calyx, (2) stalk width in the middle area of the stalk length, (3) calyx length from the junction of the stalk to the calyx rim at the connection point of anchors/primary tentacles, (4) calyx diameter in the height of anchors/primary tentacles, (5) arm length from the calyx rim at the connection point of anchor/primary tentacle to the connection point of the secondary tentacles, (6) anchor height, and (7) anchor width. Ratios (stalk/calyx length, calyx length/width $(1 / w)$, anchor height/width, stalk width/anchor height) were calculated from the measurements. Detailed photographs on external morphological features were taken from living specimens collected in 2012.

Complete $80 \%$ ethanol-preserved specimens of C. convolvulus $(n=3)$ and H. tenuis $(n=3)$ as well as $80 \%$ ethanol-preserved body parts of $H$. auricula specimens $(n=4)$ were used for morphological investigations (Table 1). External morphological features (number of secondary tentacles, shape of anchors [if present], location of nematocyst clusters [if present], as well as internal structures (number of gonad vesicles, shape of internal arm structures), were investigated. Additionally, a formalin-preserved arm of $H$. auricula (specimen Ha4, Table 1) was used for the investigation of internal arm structures. Preparations of the arm structures and gonads were conducted with micro scissors. Speciesspecific differences in numbers of secondary tentacles and gonad vesicles were tested with the Kruskal-Wallis one-way analysis of variance (ANOVA) on ranks and Dunn's post hoc tests (SigmaPlot 12.5). Voucher specimens were deposited at the Zoological Museum Hamburg, Germany (Table 1).

\section{Nematocyst analyses}

The nematocysts of seven body regions were analyzed: (1) terminal knobs of secondary tentacles, (2) exumbrella perradial, (3) exumbrella interradial, (4) subumbrella perradial, (5) subumbrella interradial, (6) primary tentacle (for C. convolvulus) or anchor (for Haliclystus spp.), and (7) gastric filaments. (For details on the body parts analyzed for each specimen, see Online Resource 1). The dissection of body parts was conducted with micro scissors. Secondary tentacle knobs, gastric filaments, primary tentacles, and anchors were completely analyzed. The analyses of exumbrella and subumbrella tissues were started at the bell rim and continued
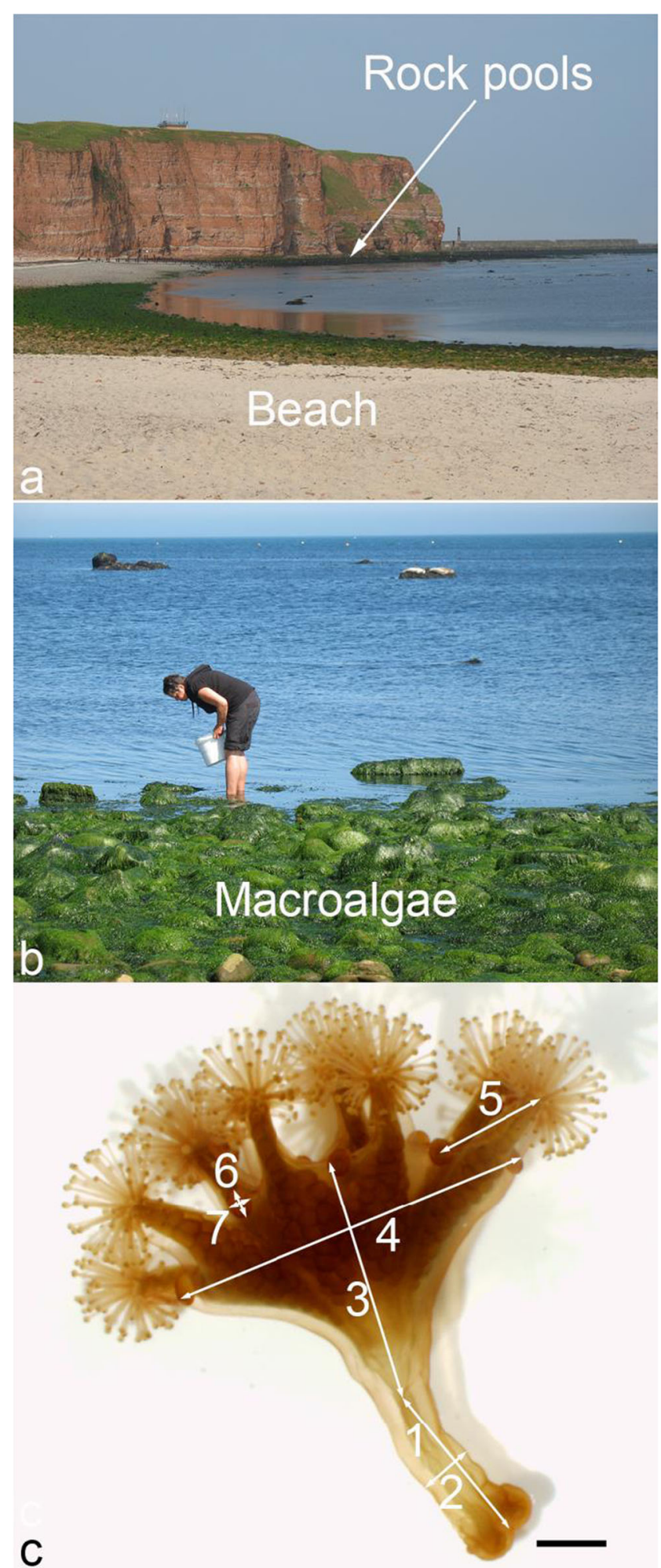

Fig. 1 Sampling site and morphometric parameters of Staurozoa. a Helgoland northern beach and nearby rock pools at low tide; b Sampling of staurozoans in the ankle-deep to knee-deep water in the intertidal of the northern beach at low tide; $\mathbf{c}$ Morphometric parameters measured on photographs of the collected specimens in lateral view. Scale bar $=2 \mathrm{~mm}$ 
along the radii. The measurement of 40 undischarged capsules was targeted for each capsule type in each body region. If less than ten capsules were found, the type was considered as rare. Capsule types appearing only once in the examined body part were excluded from the analysis. The dissected tissues were transferred on a microscopic slide in a drop of tap water. A coverslip was applied with gentle pressure. The preparation was searched for nematocysts with a light microscope (Leitz Dialux 22, interference contrast, $\times 100$ oil), and undischarged and discharged nematocysts were photo documented (Leica DFC 280). Lengths and widths of undischarged capsules appearing in side view with clearly visible contours were measured. The identification of nematocyst types was based on the nomenclature of Östman and Hydman (1997) and Östman (2000). Capsule volumes were calculated according to Purcell and Mills (1988): $V=4 / 3 \times \pi \times a \times b 2$, where $a$ is half the capsule length and $b$ is half the capsule width. Species-specific comparisons of capsule volumes and length/width $(1 / w)$ ratios were conducted by the KruskalWallis one-way analysis of variance on ranks and Dunn's post hoc tests or the Mann-Whitney rank sum test, respectively (SigmaPlot 12.5).

\section{Molecular genetic analyses}

Genomic DNA was extracted from the tentacle clusters (fixed in $80 \%$ or $96 \%$ absolute ethanol) of a total of 21 staurozoan specimens using the QIAGEN DNeasy blood and tissue kit (QIAGEN) following the manufacturer's protocol with an overnight lysis. Three gene fragments were amplified and analyzed: mitochondrial COI and $16 \mathrm{~S}$ and nuclear $18 \mathrm{~S}$ rDNA. For DNA extracts from $H$. tenuis of which COI was analyzed by Holst and Laakmann (2019), 16S and 18S rDNA were analyzed. Amplifications were accomplished by illustra PuRe Taq Ready-To-Go PCR Beads (GE Healthcare) using $4 \mu \mathrm{L}$ of DNA templates in $25 \mu \mathrm{L}$ reaction volumes. Amplification and sequencing of 18S rDNA were conducted according to Laakmann et al. (2013) using the primer pairs $18 \mathrm{~A} 1 \mathrm{mod}$ and $1800 \mathrm{mod}$ (Raupach et al. 2009) with a thermoprofile of denaturation of $94{ }^{\circ} \mathrm{C}(5 \mathrm{~min}) ; 36$ cycles at $95{ }^{\circ} \mathrm{C}(45 \mathrm{~s}), 50{ }^{\circ} \mathrm{C}(50 \mathrm{~s})$, and $72{ }^{\circ} \mathrm{C}(2 \mathrm{~min})$; and final elongation at $72{ }^{\circ} \mathrm{C}(5 \mathrm{~min})$. In some cases, the modified primer 18A1new (5'-CCTAYCTGGTTGATCCTGCCAGT$3^{\prime}$ ) was used. For sequencing, we used the internal primers F1, CF2, CR1, and R2 (Laakmann et al. 2013). COI was amplified using the primer pairs LCO1490 and HCO2198 (Folmer et al. 1994) and LCO1490 and Nancy (Simon et al. $1994)$ with a thermoprofile of denaturation at $94-95{ }^{\circ} \mathrm{C}$ (5 min), followed by $94-95{ }^{\circ} \mathrm{C}(45 \mathrm{~s}), 42-45^{\circ} \mathrm{C}(45-50 \mathrm{~s})$, and $72{ }^{\circ} \mathrm{C}(60-80 \mathrm{~s})$ for 38 cycles, and final elongation at $72{ }^{\circ} \mathrm{C}$ (5 min). For some samples, touchdown PCR was conducted with an initial step at $94{ }^{\circ} \mathrm{C}(120 \mathrm{~s}) ; 5$ cycles at $96{ }^{\circ} \mathrm{C}$ $(60 \mathrm{~s}), 45^{\circ} \mathrm{C}(90 \mathrm{~s})$, and $72{ }^{\circ} \mathrm{C}(90 \mathrm{~s}) ; 35$ cycles at $93{ }^{\circ} \mathrm{C}(60 \mathrm{~s})$,
$50{ }^{\circ} \mathrm{C}(90 \mathrm{~s})$, and $72{ }^{\circ} \mathrm{C}(90 \mathrm{~s})$; and final elongation at $72{ }^{\circ} \mathrm{C}$ (5 min). The $16 \mathrm{~S}$ was amplified with denaturation at $95^{\circ} \mathrm{C}$ (5 min), followed by $95{ }^{\circ} \mathrm{C}(30-45 \mathrm{~s}), 45^{\circ} \mathrm{C}(50 \mathrm{~s})$, and $72{ }^{\circ} \mathrm{C}$ ( $1 \mathrm{~min}$ ) for 38 cycles, and final elongation at $72{ }^{\circ} \mathrm{C}(5 \mathrm{~min})$ using the primer pair F1Mod (Cunningham and Buss 1993, modified by Cartwright et al. 2008) and R2 (Cunningham and Buss 1993). PCR products were purified using QIAquick PCR Purification Kit (QIAGEN) or by the incubation of $20 \mu \mathrm{L}$ PCR product together with $8 \mu \mathrm{L}$ ExoSAP (Thermo Fisher Scientific) for $15 \mathrm{~min}$ at $37^{\circ} \mathrm{C}$ and for $15 \mathrm{~min}$ at $80^{\circ} \mathrm{C}$. Both cycle sequencing and sequencing were performed at Macrogen (Amsterdam, Netherlands) and GATC (Konstanz, Germany).

Sequences were assembled, edited, and checked for reading frames (COI) using the software Geneious (version 7.1.9) created by Biomatters (http://www.geneious.com; Kearse et al. 2012). All sequences generated in this study were deposited in GenBank with accession numbers MF322725MF322746 and MF346293-MF346312 (see Table 1). In order to compare the sequences from our specimens to published data, COI, 16S, and 18S rDNA sequences for the three species and for Haliclystus congeners were downloaded from GenBank (see Online Resource 2) and were included in the analyses. Also, the $16 \mathrm{~S}$ and $18 \mathrm{~S}$ rDNA sequences declared as Microhydrula limopsicola Jarms and Tiemann, 1996 (EU294003 and EU247811 from ZMUH culture in Hamburg, Germany, originally derived from the Argentine Antarctic Station "Jubany" (King George Island, South Shetland Islands)), and later identified as an early life stage of Haliclystus antarcticus Pfeffer, 1889 (Miranda et al. 2010; see also Miranda et al. 2016b) were downloaded and integrated in our data sets. The scyphozoan Cyanea capillata (Linnaeus, 1758) was used as an outgroup taxon for the analysis of all three gene fragments (Online Resource 2). For all three gene fragments (COI, 16S, and 18S rDNA), the multiple alignments, neighbor joining trees, and maximum likelihood trees are available in Dryad digital repository (https://doi.org/ 10.5061/dryad.5cr6008).

Multiple alignments were performed using MUSCLE (version 3.8.1; Edgar 2004) at default settings resulting in multiple alignments of $1721 \mathrm{bp}$ for $18 \mathrm{~S}$ rDNA, $648 \mathrm{bp}$ for COI, and $595 \mathrm{bp}$ for $16 \mathrm{~S}$. For molecular species differentiation, neighbor joining (NJ) (Saitou and Nei 1987) and maximum likelihood (ML) analyses were applied. NJ analyses were conducted in MEGA6 (Tamura et al. 2013) using the $p$-distance method (Nei and Kumar 2000), pairwise deletion, and 10,000 bootstrap replicates (Felsenstein 1985). Branches corresponding to partitions reproduced in less than $50 \%$ bootstrap replicates were collapsed. The evolutionary distances were computed using $p$-distances (Nei and Kumar 2000). ML analyses were performed using the software IQTree (Nguyen et al. 2015). For this, a best-fit evolutionary model was identified using ModelFinder (Kalyaanamoorthy et al. 2017). The model with 
the best-corrected Akaike information criterion (AICc) was chosen for ML analyses (i.e., 16S: TIM2+F+G4, COI: GTR+F+I+G4, 18S rDNA: $\mathrm{TN}+\mathrm{F}+\mathrm{I})$ (Tamura and Nei 1993 ) with the generation of 10,000 bootstrap replicates by using ultrafast bootstrapping (Hoang et al. 2018). Trees were displayed in FigTree (v1.4.3 http://tree.bio.ed.ac.uk/software/ figtree/).

\section{Proteomic fingerprinting}

The analysis of proteomic fingerprinting using the MALDITOF MS technology was performed according to modified protocols published by Riccardi et al. (2012) and Laakmann et al. (2013). Tentacle clusters of 18 specimens, fixed in $80 \%$ and $96 \%$ absolute ethanol, were analyzed. Just before protein extraction, excess ethanol was removed from the tentacle clusters using lint-free wipes. Subsequently, the tentacle clusters were incubated for $10 \mathrm{~min}$ at dark conditions in $10 \mu \mathrm{L}$ of matrix solution (alpha-cyano-4-hydroxycinnamic acid (HCCA) as a saturated solution in $50 \%$ acetonitrile and $2.5 \%$ trifluoroacetic acid). Homogenate was vortexed for $10 \mathrm{~s}$ and centrifuged for $20 \mathrm{~s}$ at $13,000 \mathrm{rpm}$, and $1.2 \mu \mathrm{L}$ of the supernatant was spotted in three replicates on a target plate and allowed to evaporate at room temperature for several minutes under an exhaust hood. The analyses were performed on a compact linear-mode benchtop microflex LT system (Bruker Daltonics) at a laser frequency of $60 \mathrm{~Hz}$. Before analyses, the system was calibrated using a bacterial test standard (Bruker Daltonics) containing a protein extract of Escherichia coli DH5alpha. Mass spectra were analyzed between 2000 and 20,000 Da. One final spectrum for each technical replicate consisted of $3 \times 240$ laser shots at fixed optical laser energy and a pulse of $3 \mathrm{~ns}$.

The analyses of the proteomic mass spectra $(2000$ 20,000 Da) were performed in $\mathrm{R}$ (version 3.1.3; R Core Team 2015) using the MALDIquantForeign $\mathrm{R}$ package (version 0.9; Gibb 2014) and MALDIquant package (version 1.12; Gibb and Strimmer 2012) for species identification. Here, we performed square root transformation, smoothing of mass spectra (Savitzky-Golay filter, half window size 10), baseline correction (SNIP algorithm with 25 iterations), and normalization in order to equalize intensities across spectra (total ion current (TIC) calibration). A signalto-noise ratio of 3 was removed. Peaks occurring in $<100 \%$ of measurements were removed, and remaining peaks were binned (0.002). Mass spectra of all technical replicates of one sample were merged. In the end of the processing, feature matrices (absolute values, relative intensities, and binary matrix) were generated.

By applying the vegan R package (version 2.3-0; Oksanen et al. 2015) and the pvclust R package (version 1.3-2; Suzuki and Shimodaira 2014), hierarchical cluster analyses based on Euclidian distance matrices were conducted based on absolute values, relative intensities (Hellinger transformation), and binary values using Ward's minimum variance method and bootstrapping analysis (1000 replicates).

\section{Results}

\section{Macromorphology}

The morphologically examined specimens were composed of a pedal disc attached to the substrate, a slim stalk (peduncle), and a funnel-shaped calyx at the upper (oral) end. Stalk and calyx were similar in length in $H$. tenuis and $H$. auricula (mean stalk/calyx length ratios $0.8 \pm 0.0$ and $0.9 \pm 0.3$ ) whereas the stalk was much shorter than the calyx in $C$. convolvulus (mean ratio $0.4 \pm 0.1$ ) (Table 2). Eight arms arose from the calyx margin of each examined specimen, each ending in a cluster of capitate (knobbed) tentacles. The small mean calyx $1 / \mathrm{w}$ ratio of $H$. auricula $(0.5 \pm 0.2)$ reflected the wider calyx shape compared to $H$. tenuis $(1.1 \pm 0.1)$ and $C$. convolvulus $(1.2 \pm 0.1)$ (Fig. $2 \mathrm{a}-\mathrm{c})$. In both Haliclystus species, roundish to oval anchors appeared at the calyx margin in the clefts between adjacent arms. The anchors were slightly wider than high in H. tenuis (Fig. 2d) (mean anchor height/width ratio $0.9 \pm 0.0$ ) but slightly higher than wide in H. auricula (Fig. 2e) (mean ratio $1.3 \pm 0.0$ ). The anchor heights were about half of the stalk diameters in both Haliclystus species (stalk width/ anchor height ratios $1.8 \pm 0.3$ and $2.1 \pm 0.2)$. In C. convolvulus, anchors were absent but small capitate knobs, representing the remnants of primary tentacles, appeared in the clefts between adjacent arms (Fig. 2f). Anchors or primary tentacles, respectively, were oriented to the outer calyx side (exumbrella).

The inner side of the tentacles and the adjacent mouth field, surrounding the cross-shaped mouth, represented the subumbrella (Fig. 2g, h). The cruciform-arranged mouth lips reflected an octoradial symmetry with four perradii located in line with the mouth lips and the interradii located in line with the clefts between the lips (Fig. $2 g$, h). The anchors of the Haliclystus species and primary tentacles of $C$. convolvulus were oriented perradially and interradially, and the arms were oriented in the axes between (adradial). In H. tenuis (Fig. 2d) and C. convolvulus (Fig. 2h), white spots of nematocyst clusters were present on the interradial and perradial subumbrella bell margin and along the perradial subumbrella between the gonads. In the side view of living specimens, the nematocyst spots appeared as scattered white dots in the perradii, visible through the calyx in $H$. tenuis (Fig. $2 \mathrm{~d}$ ), whereas the white nematocyst spots were not visible through the calyx in side view in C. convolvulus (Fig. 2c, f). In H. auricula, white spots of nematocyst clusters were absent (Fig. 2e, g). In all three species, the gonads were organized in four pairs separated by interradial septa. The gonads appeared as globular vesicles 


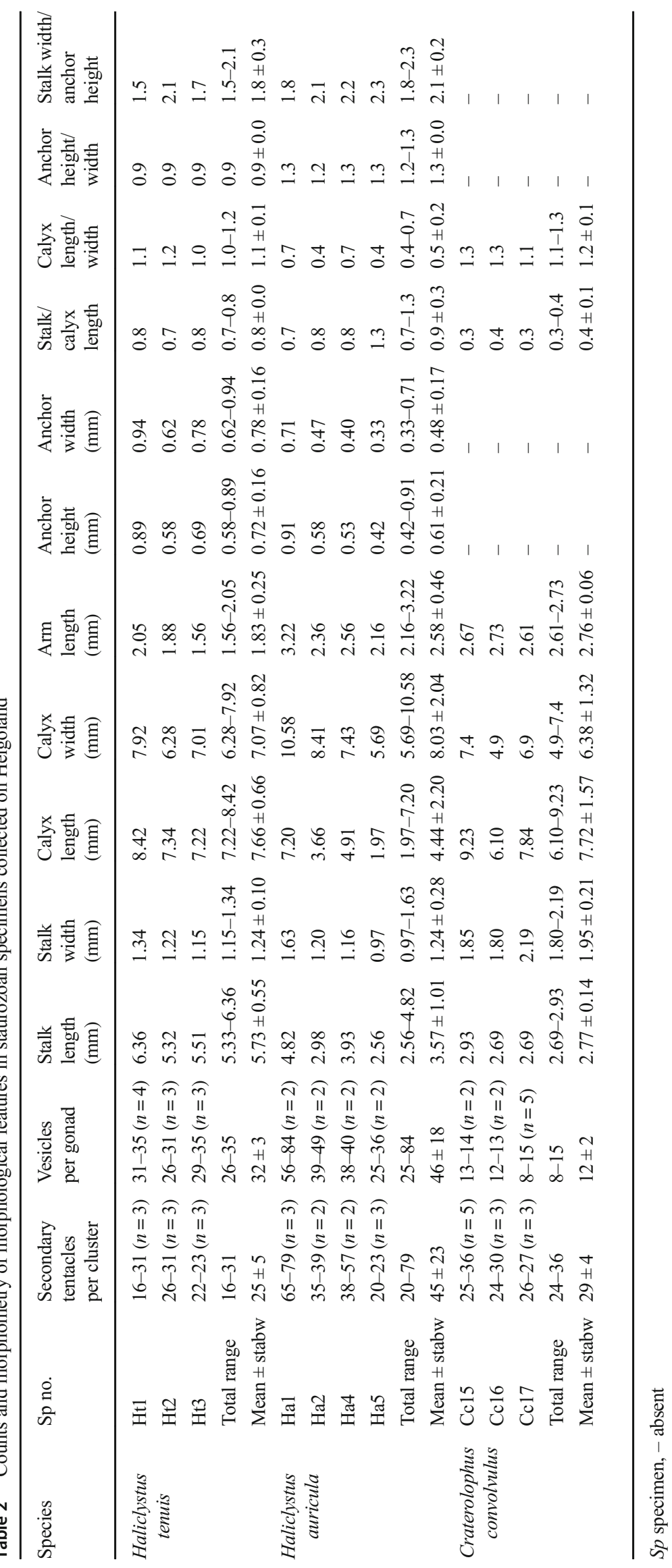




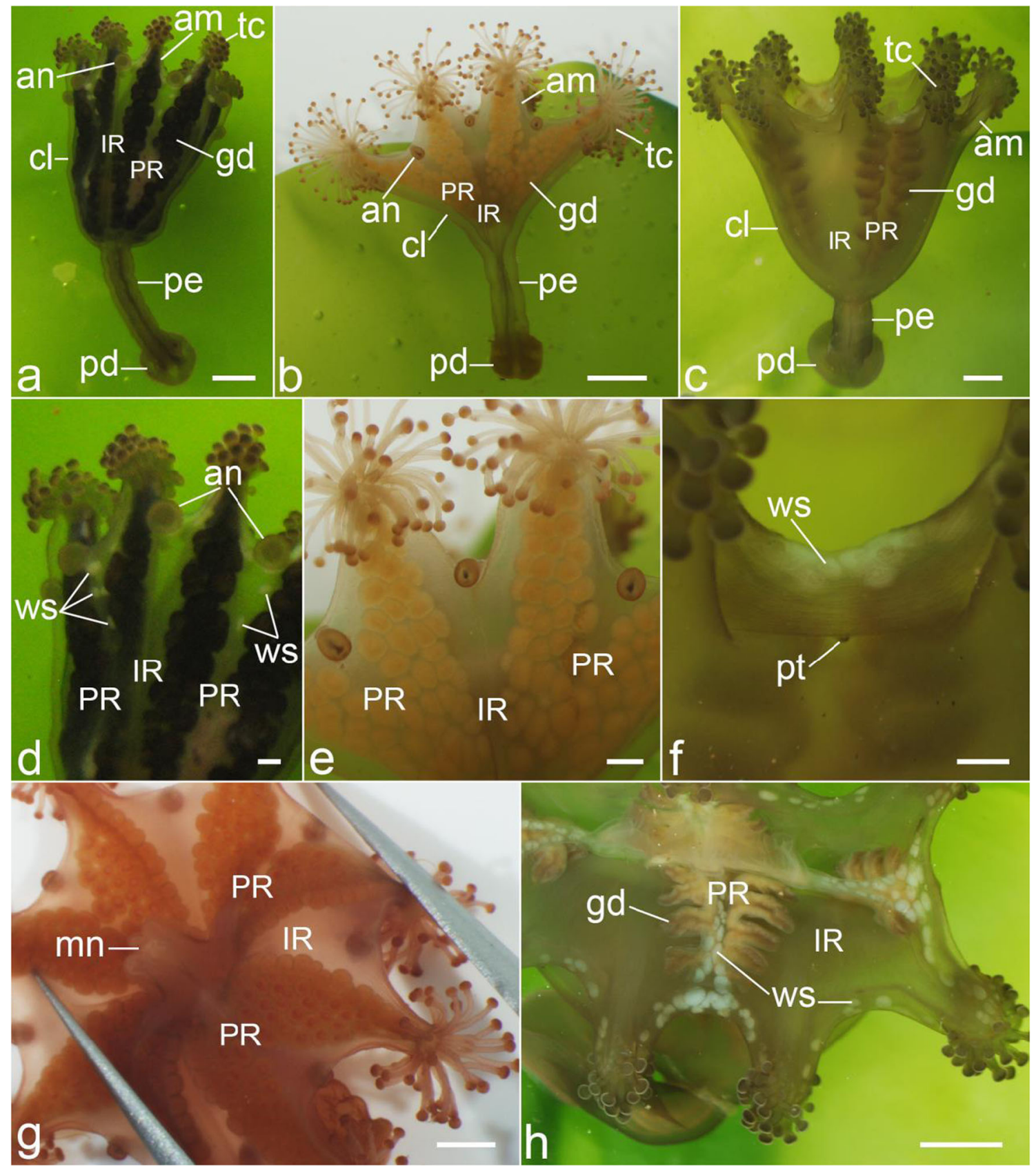

Fig. 2 External morphology of staurozoans collected on Helgoland. a, d Haliclystus tenuis; b, e, g Haliclystus auricula; $\mathbf{c}, \mathbf{f}, \mathbf{h}$ Craterolophus convolvulus; a-c Living specimens in side view; $\mathbf{d}-\mathbf{f}$ External morphological details in side view; $\mathbf{g}$, h External morphological details

extending into the adradial arms in both Haliclystus species (Fig. 2d, e, g). In contrast, the gonads appeared in pockets with a featherlike arrangement extending to the bell margin in C. convolvulus (Fig. 2c, h). The vesicles were fewer in the gonads of $H$. tenuis specimens (mean $32 \pm 3, n=10$ ) which had larger calyces (mean length $7.66 \pm 0.66 \mathrm{~mm}$, mean width $7.07 \pm 0.82 \mathrm{~mm}$ ) compared to $H$. auricula specimens (mean no. $46 \pm 18, n=8$ ) which had shorter but wider calyces (mean length $4.44 \pm 2.20 \mathrm{~mm}$, mean width $8.03 \pm 2.04 \mathrm{~mm}, n=4$ ) in oral view. am arm, an anchor, $c l$ calyx, $g d$ gonad, $I R$ interradius, $m n$ manubrium, $p d$ pedal disc, $p e$ peduncle, $P R$ perradius, $p t$ primary tentacle, $t c$ tentacle cluster, $w s$ white spot of nematocysts. Scale bars $=2 \mathrm{~mm}(\mathbf{a}-\mathbf{c}$, $\mathbf{g}, \mathbf{h})$ and $0.5 \mathrm{~mm}(\mathbf{d}-\mathbf{f})$

(Table 2). Specimens of C. convolvulus had calyces of similar size (mean length $7.72 \pm 1.57 \mathrm{~mm}$, mean width $6.38 \pm$ $1.32 \mathrm{~mm}, n=3)$ as $H$. tenuis, and the mean number of pockets per gonad was $12 \pm 2(n=9)$. The number of vesicles/pockets per gonad differed significantly among the species (ANOVA on ranks: $p<0.001$; for details of test statistics, see Online Resource 3) (Fig. 3a). However, the post hoc test revealed no significant difference between $H$. tenuis and $H$. auricula (post hoc: $p>0.05$ ). The number of secondary 

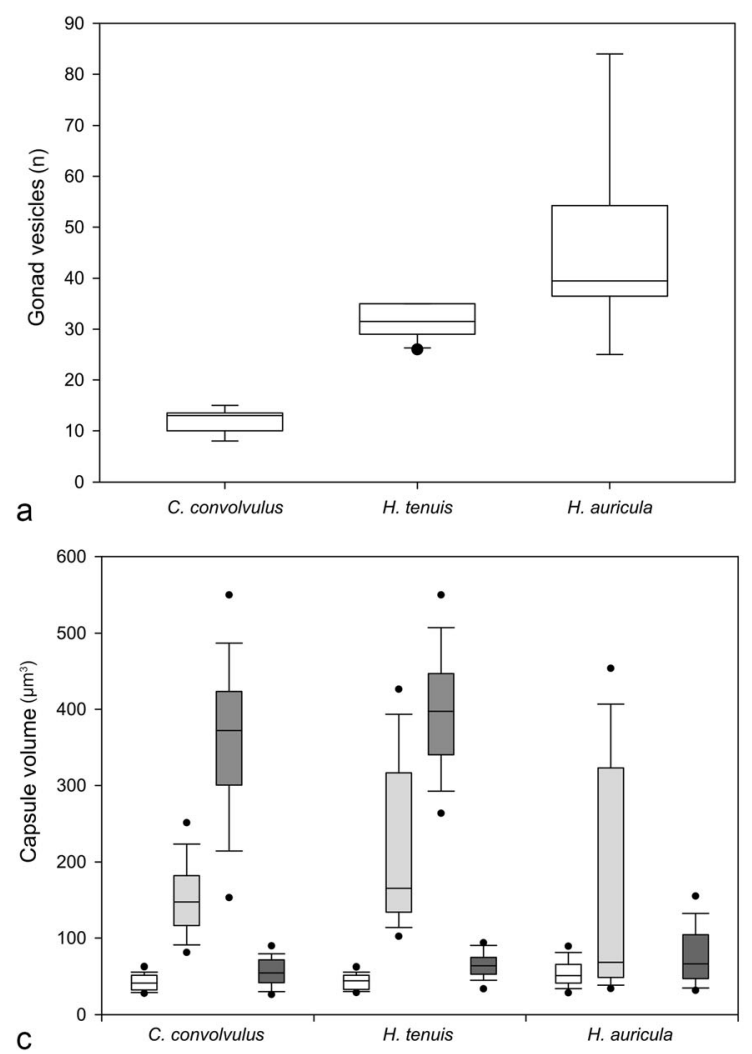

Fig. 3 Box plots of statistically analyzed data on morphological features and nematocyst measurements. a Numbers of vesicles $\operatorname{gonad}^{-1} ; \mathbf{b}$ Numbers of secondary tentacles cluster ${ }^{-1}$; $\mathbf{c}$ Nematocyst capsule volumes; d Nematocyst capsule length/width ratios. Box plots with

tentacles was lower in $H$. tenuis (mean no. $25 \pm 5, n=9$ ) than in H. auricula (mean no. $45 \pm 23, n=10$ ) and was in between in C. convolvulus (mean no. $29 \pm 4, n=11$ ). Although the variation of secondary tentacle numbers was high in $H$. auricula, there was a significant difference in tentacle numbers between $H$. auricula and $H$. tenuis but not between C. convolvulus and the two Haliclystus species (ANOVA on ranks: $p=0.047$; post hoc: $p \geq 0.05$ ) (Fig. 3b).

Longitudinal sections through the arms revealed differences in the internal arm structures between the species. In H. tenuis, the tentacle bases were connected to the arms by a protrusion located at the exumbrella side of the arm (Fig. 4a). In contrast, lobule-like extensions of the tentacles were present at the tentacle bases of $H$. auricula (Fig. $4 \mathrm{~b}, \mathrm{c}$ ) and C. convolvulus (Fig. 4d). The preparation of the arms of the ethanol-preserved specimens was challenging because of the high dehydration of the samples resulting in severe shrinkage and deformation. In Haliclystus specimens, the gonad vesicles had to be removed carefully from the upper part of the arm (Fig. 4a, b) to allow a view on the tentacle bases of ethanolpreserved specimens. The ethanol-preserved material tended to disintegrate during preparation whereas the handling of formalin-preserved arms of $H$. auricula was much more feasible and gonad vesicles had not to be removed (Fig. 4c).
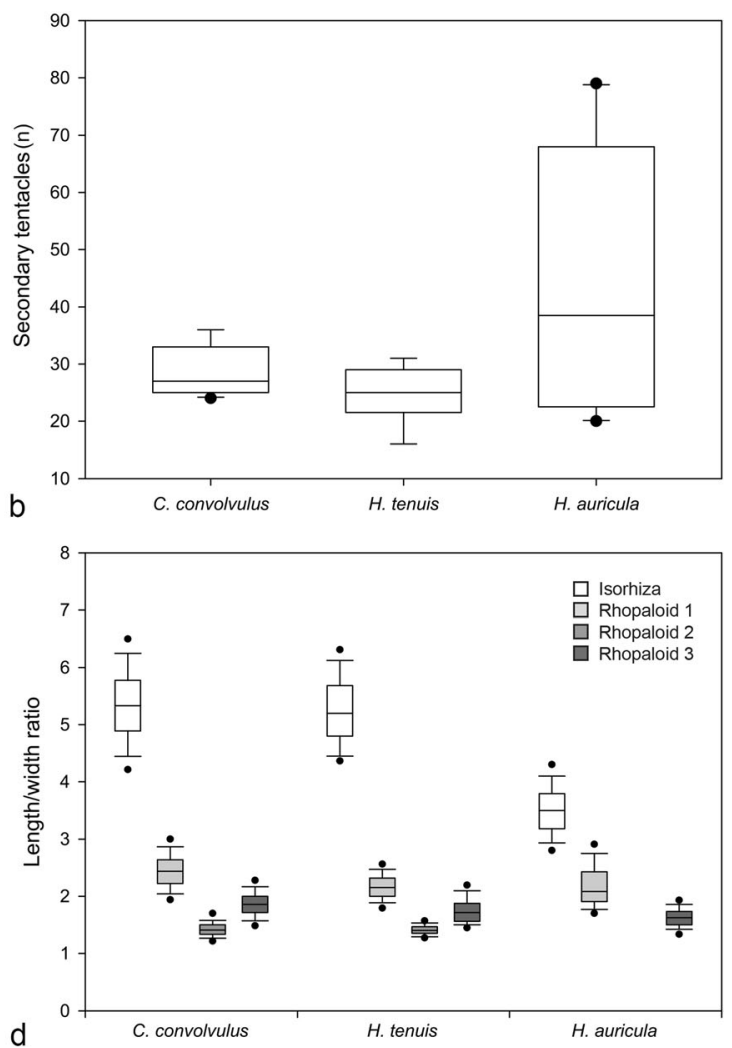

medians, 25th/75th percentiles (whiskers), and 5th/95th percentiles (black dots). For details of replicates and test statistics, see Online Resource 3

\section{Nematocyst analyses}

The preparation in fresh water allowed the documentation of large numbers of undischarged nematocysts and a few discharged capsules. Isorhizas (tubule without shaft) and three types of rhopaloids (tubule with shaft) were identified (Fig. 5, Table 3). The rhopaloids were termed type 1 to type 3 because ambiguous photographs of discharged nematocysts did not allow a clear classification of rhopaloids as eurytele (shaft with one distal dilation) or as birhopaloid (shaft with two dilations). However, most photographs on discharged capsules indicated the occurrence of one eurytele (rhopaloid type 1) (Fig. 5n) and two types of birhopaloids (rhopaloid types 2 and 3) (Fig. 5o, p).

Rhopaloid type 2 had the largest volumes and rhopaloid type 1 the second largest ones, while the volumes of isorhizas and rhopaloid type 3 were significantly smaller (Fig. 3c). The capsule volumes differed significantly among each of the four nematocyst types in each species (ANOVA on ranks: $p<0.01$; post hoc: $p<0.05$ ) (Online Resource 3). The capsule volumes of isorhizas were similar in all three species (Fig. 3c); however, the $1 / \mathrm{w}$ ratios of $H$. auricula isorhizas $(3.4 \pm 0.5)$ differed significantly to those of $C$. convolvulus $(5.4 \pm 0.7)$ and H. tenuis $(5.3 \pm 0.6)$ (ANOVA on ranks: $p<0.001$; post hoc: 
Fig. 4 Internal structure of staurozoan arms. a Haliclystus tenuis; b, c Haliclystus auricula. d Craterolophus convolvulus. a, b, d Longitudinal sections through ethanol-preserved arms; c Longitudinal section through formalin-preserved arm. am arm, arrows intertentacular lobules, cs connecting structure, $g v$ gonad vesicle, $t c$ tentacle cluster. Scale bars $=200 \mu \mathrm{m}$

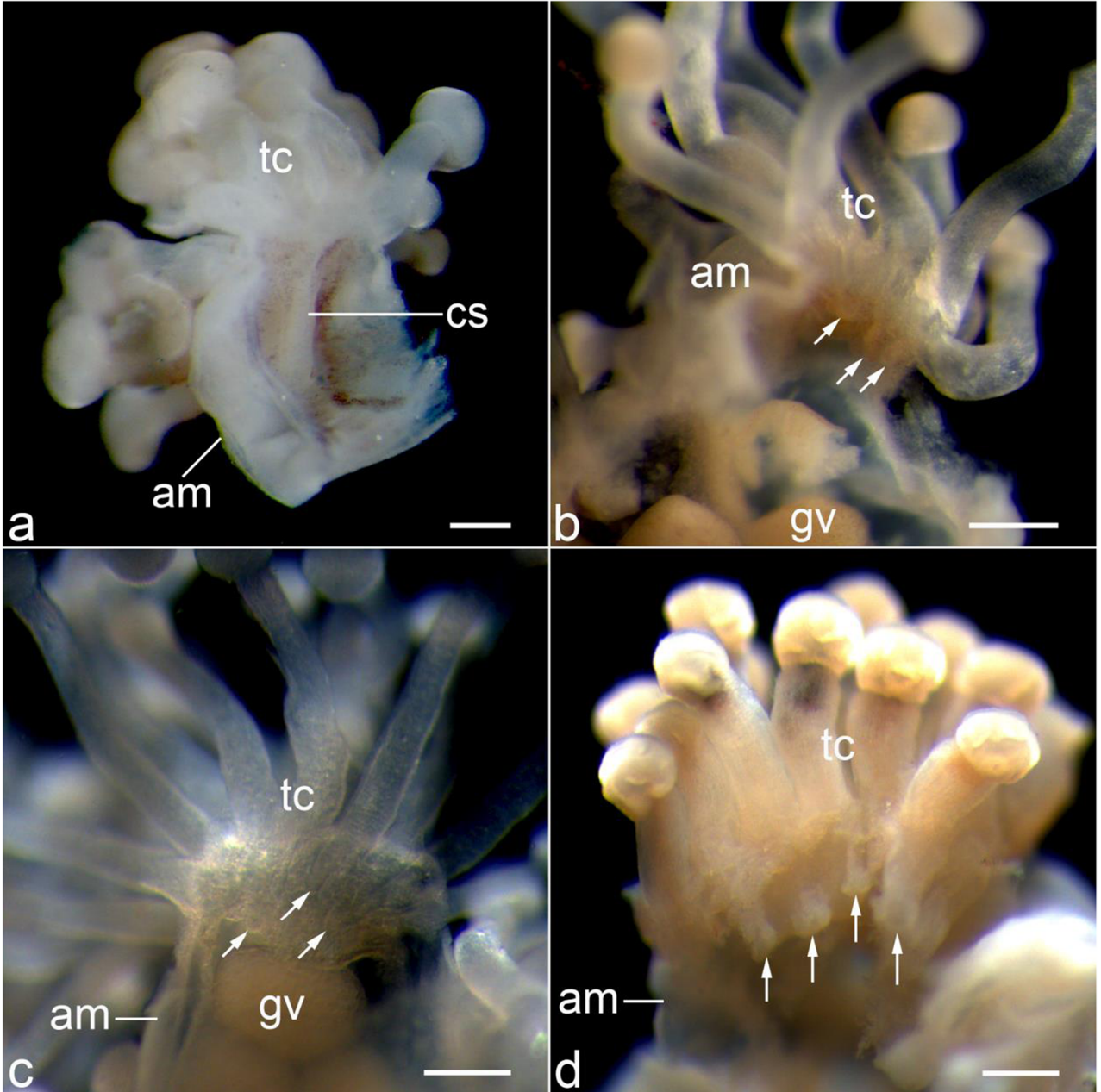

$p<0.05$ ) (Online Resource 3), reflecting a more stout shape in the first and more elongated shapes in the latter (Figs. 3d and $5 \mathrm{a}, \mathrm{e}, \mathrm{i})$. Isorhizas appeared frequently in the preparations of all investigated body parts except in the gastric filaments of any specimen and the exumbrella and anchors of $H$. tenuis specimens (Table 3 ). They were present in the anchors of only two (of four investigated) $H$. auricula specimens and in two (of three) C. convolvulus specimens.

The three rhopaloid types were distinguishable in the undischarged state by their distinct capsule shape (Fig. 5b-d, f$\mathrm{h}, \mathrm{j}-\mathrm{l}$ ). Type 1 was more elongated oval compared to the more roundish type 2. Type 3 was long oval but less elongated than type 1, and the capsules had smaller volumes (Fig. 3c). The distinct shape differences between the rhopaloid types were statistically verified by the significant differences of $1 / w$ ratios of each of the four nematocyst types in each species (ANOVA on ranks: $p<0.01$; post hoc: $p<0.05$ ) (Online Resource 3) (Fig. 3d).

The rhopaloid type 1 was the most abundant nematocyst type, present in all body parts except in the gastric filaments of any specimen and the primary tentacles of $C$. convolvulus (Table 3). This rhopaloid type was present in the anchors of all examined Haliclystus specimens (Table 3) and appeared in significantly larger sizes in the anchors of $H$. tenuis (mean volume $\left.150.0 \pm 28.7 \mu^{3}, n=141\right)$ than in H. auricula anchors $\left(56.8 \pm 21.8 \mu^{3}, n=104\right)$ (Mann-Whitney rank sum test: $p<0.001$ ) (Online Resource 3). The white nematocyst spots, present in C. convolvulus and H. tenuis, contained high numbers of rhopaloid type 2 which also rarely appeared in the exumbrella of both species (Table 3). This rhopaloid type was not present in any of the examined body regions of $H$. auricula. The rhopaloid type 3 appeared in high numbers in the gastric filaments of the three species where no other nematocyst types were documented in any specimen (Table 3). This rhopaloid type was also found in small numbers in the subumbrella of both Haliclystus species as well as in the exumbrella of C. convolvulus specimens (Table 3).

\section{Molecular genetics}

The analysis of both mitochondrial gene fragments $16 \mathrm{~S}$ and COI allowed the differentiation of the three species (H. tenuis, $H$. auricula, and $C$. convolvulus) with lower intraspecific variability than interspecific variability (Fig. 6, Table 4, 


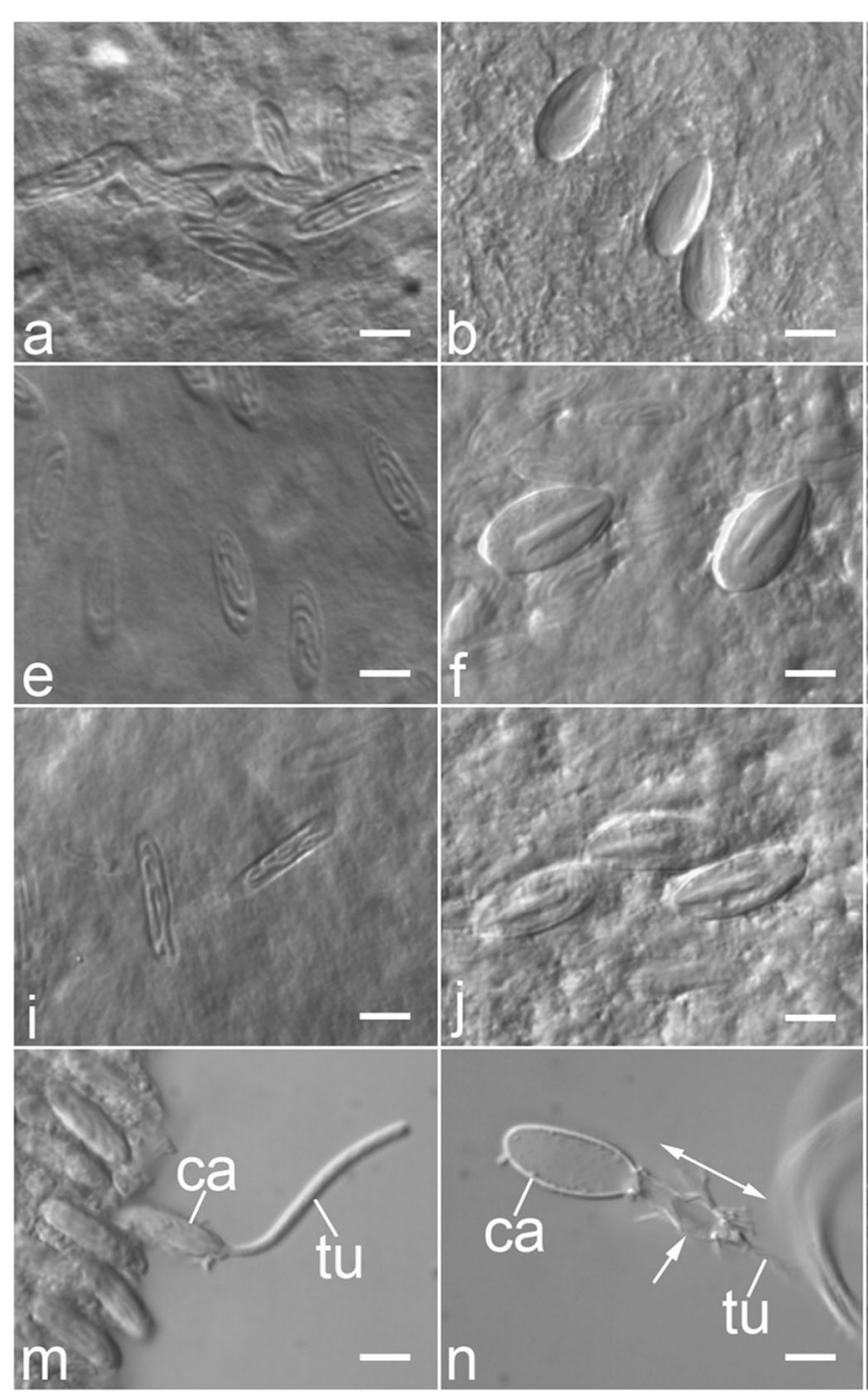

Fig. 5 Nematocyst types of Staurozoa collected on Helgoland. a-d Haliclystus tenuis; $\mathbf{e}-\mathbf{h}$ Haliclystus auricula; $\mathbf{i}-\mathbf{l}$ Craterolophus convolvulus; m-p Discharged nematocysts (m, p H. auricula, n $H$. tenuis, o $C$. convolvulus). First column isorhiza, second column

Online Resource 4). Compared to published sequence data, C. convolvulus from this study clustered with specimens of the same species from the same and different sampling locations. $H$. tenuis clustered together with specimens from Japan, and $H$. auricula was similar to specimens of $H$. antarcticus sampled in Chile and the Antarctic.

The NJ analysis of $16 \mathrm{~S}$ revealed a clear separation of the three species with all the three species clusters supported by high bootstrap values (96\%, 100\%; Fig. 6a). ML analysis resulted in high support of $C$. convolvulus species clade (95\%) and $H$. auricula clade (91\%), whereas the analysis showed lower support for the $H$. tenuis clade $(73 \%)$ (Online Resource 4a). For the three species, intraspecific variability was much lower than the interspecific one with 0 $0.6 \%$ and $13.39-22.58 \%$, respectively, resulting in a barcoding gap of $12.79 \%$. Including the sequences from

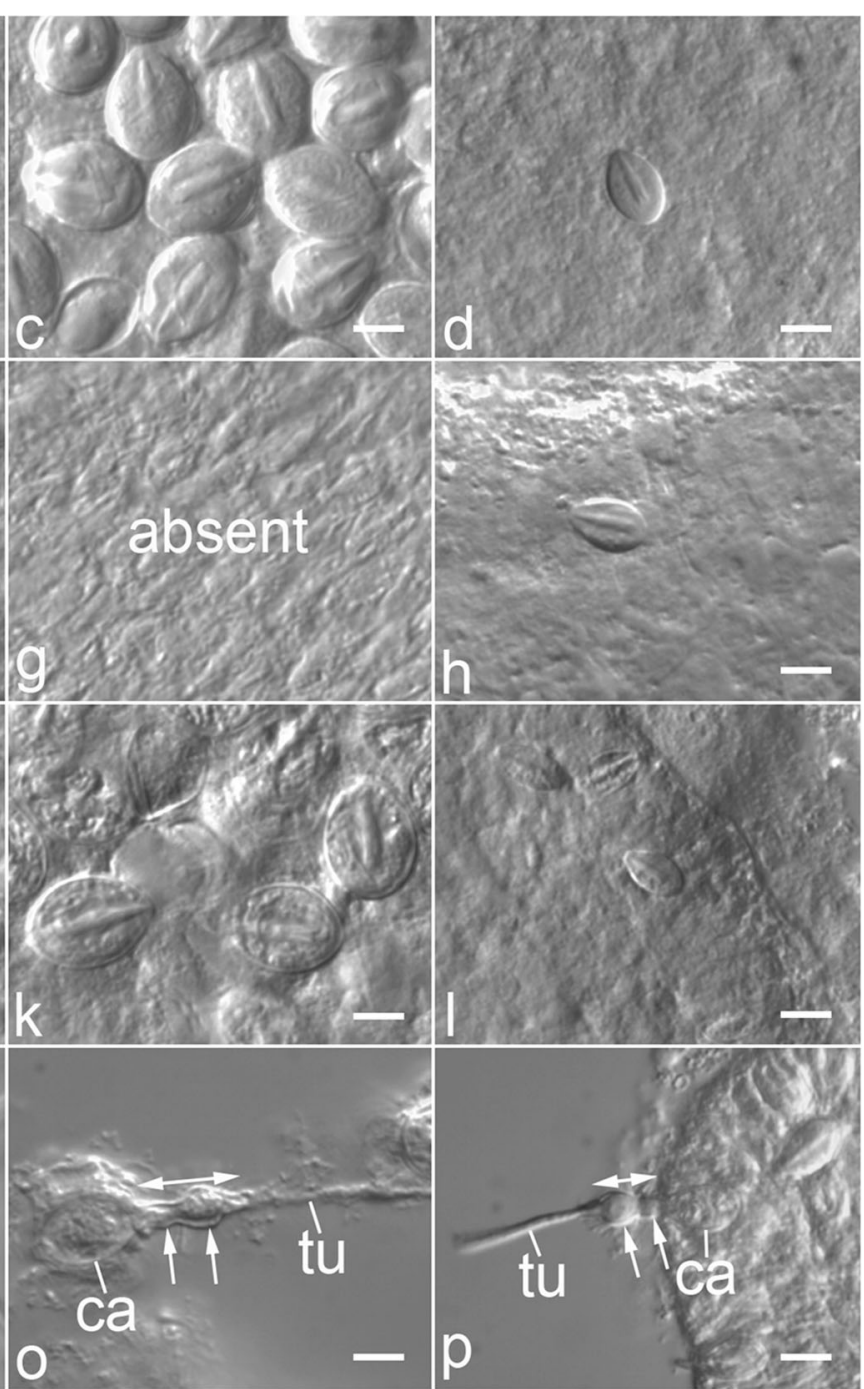

rhopaloid 1, third column rhopaloid 2, fourth column rhopaloid 3. Note significant shape and size differences between rhopaloid types. $c a$ capsule, tu tubule, left right arrow shaft span, upwards arrow shaft dilation. Scale bars $=5 \mu \mathrm{m}$

GenBank, the barcoding gap was very small with $0.36 \%$ between the intraspecific $(0-0.75 \%)$ and the interspecific $(1.11-$ $22.96 \%$ ) variabilities (Table 4 ). This small barcoding gap value is due to the small interspecific variability between $H$. auricula and $H$. antarcticus (1.11-1.57\%). In both analyses, $H$. auricula forms a cluster with $H$. antarcticus from Admiralty Bay, King George Island, Antarctica (FJ874775, Miranda et al. 2010; EU294003, Collins et al. 2008, declared as Microhydrula limopsicola, see "Material and methods"), and $H$. antarcticus from Chile (AY845340, Collins and Daly 2005), supported by $99 \%$ (NJ) and 50\% (ML) bootstrap support (Fig. 6a, Online Resource 4a). Intraspecific variability in $H$. auricula was $0-0.35 \%$ and $0-0.75 \%$ in $H$. antarcticus. Haliclystus tenuis showed an intraspecific variability of 0 $0.18 \%$ and clustered together with $H$. tenuis from Hokkaido, Japan (HM022154, Miranda et al. 2010). Craterolophus 


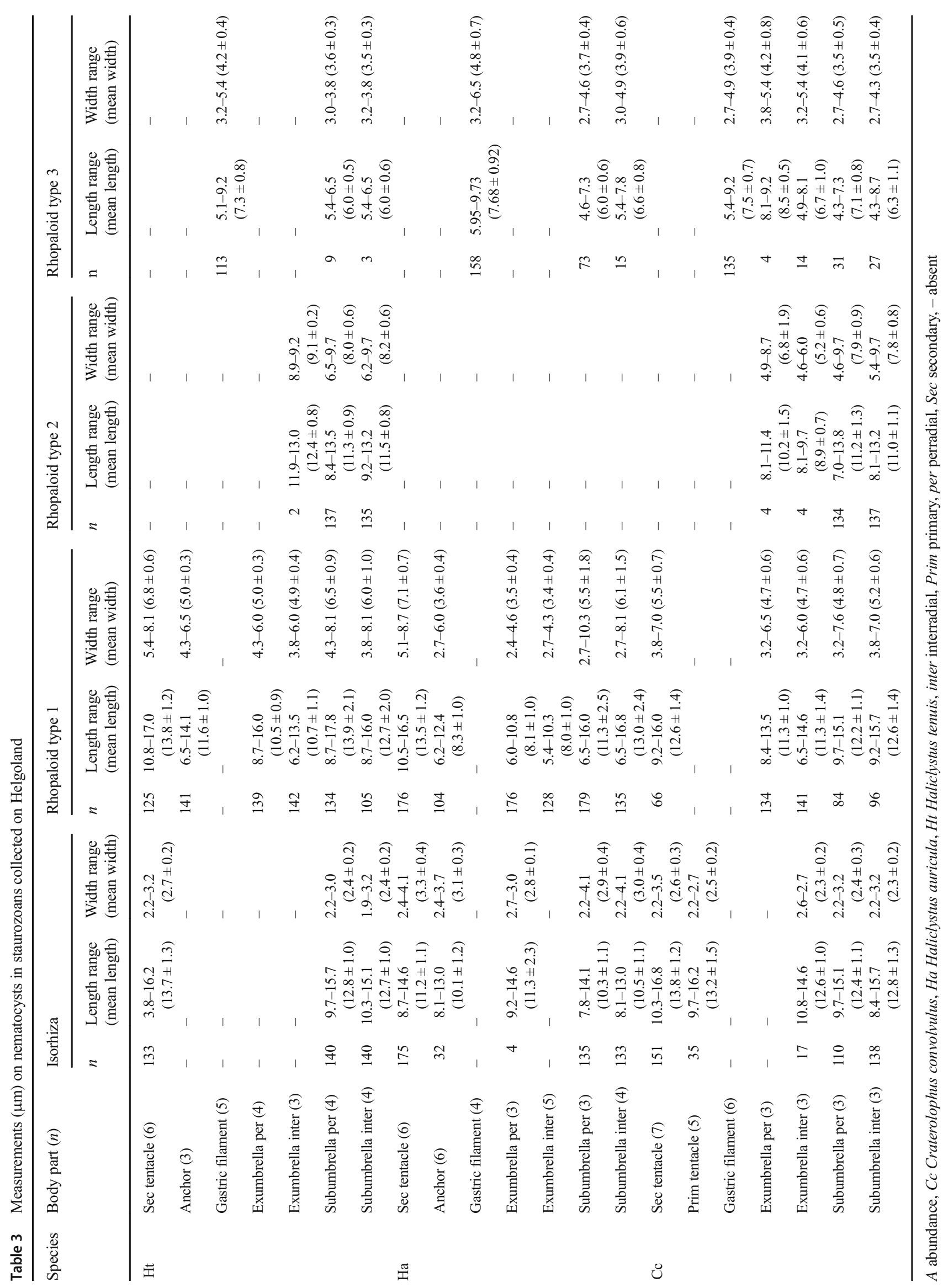




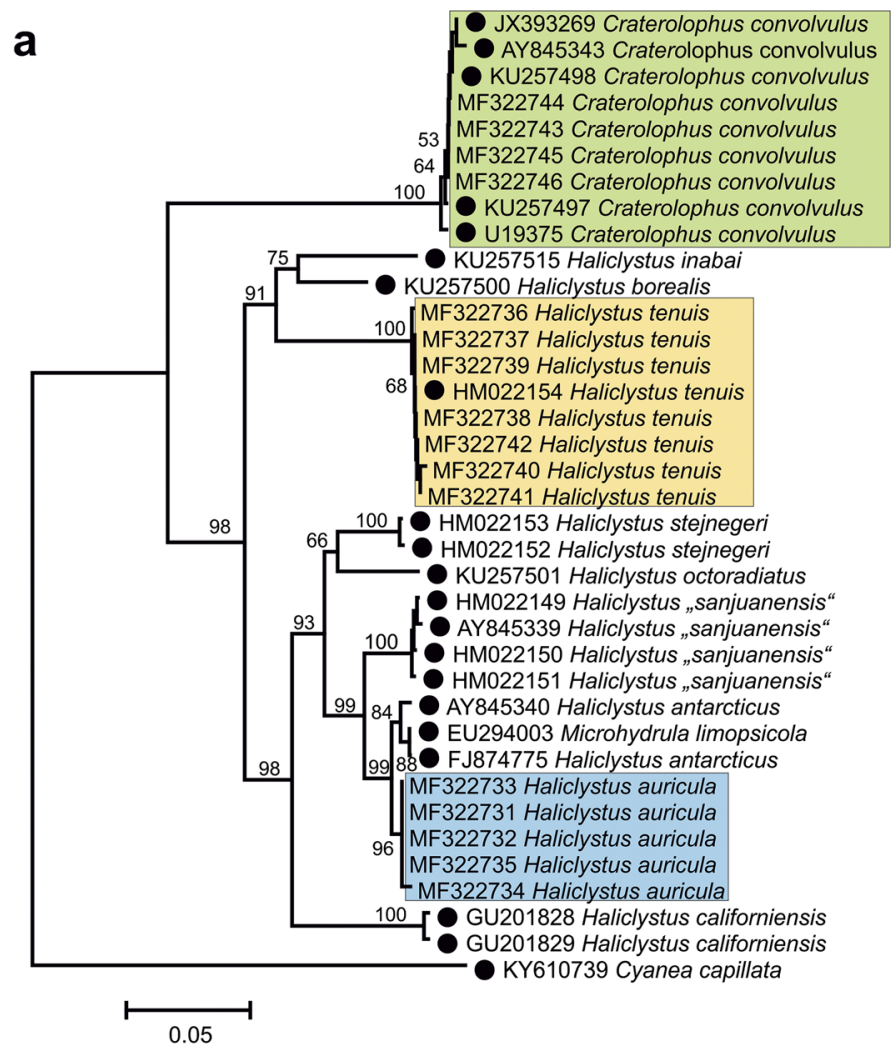

C

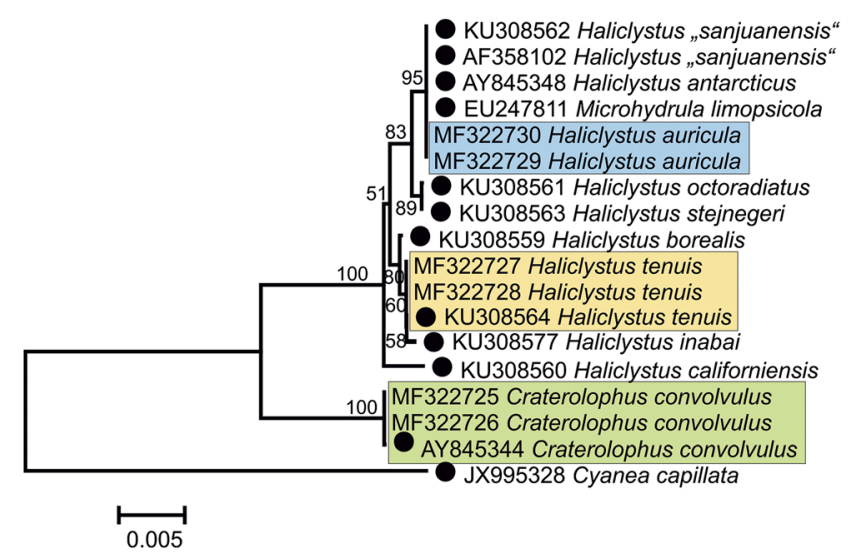

Fig. 6 Neighbor joining analyses of the different gene fragments for Craterolophus convolvulus and Haliclystus species analyzed in this study and downloaded from GenBank based on $p$-distances and 10,000 bootstrap replicates. Bootstrap values $>50 \%$ are shown. Sequences from

convolvulus clustered together with specimens from Helgoland (AY845343, Collins and Daly 2005), Cornwall, England, UK (KU257497, Miranda et al. 2016b), as well as with specimens from Rye, New Hampshire, USA (KU257498, Miranda et al. 2016b), the Northwest Atlantic, USA (JX393269, Sparmann et al., unpublished), and one unspecified location (U19375, Bridge et al. 1995) with an intraspecific variability of $0-0.60 \%$.

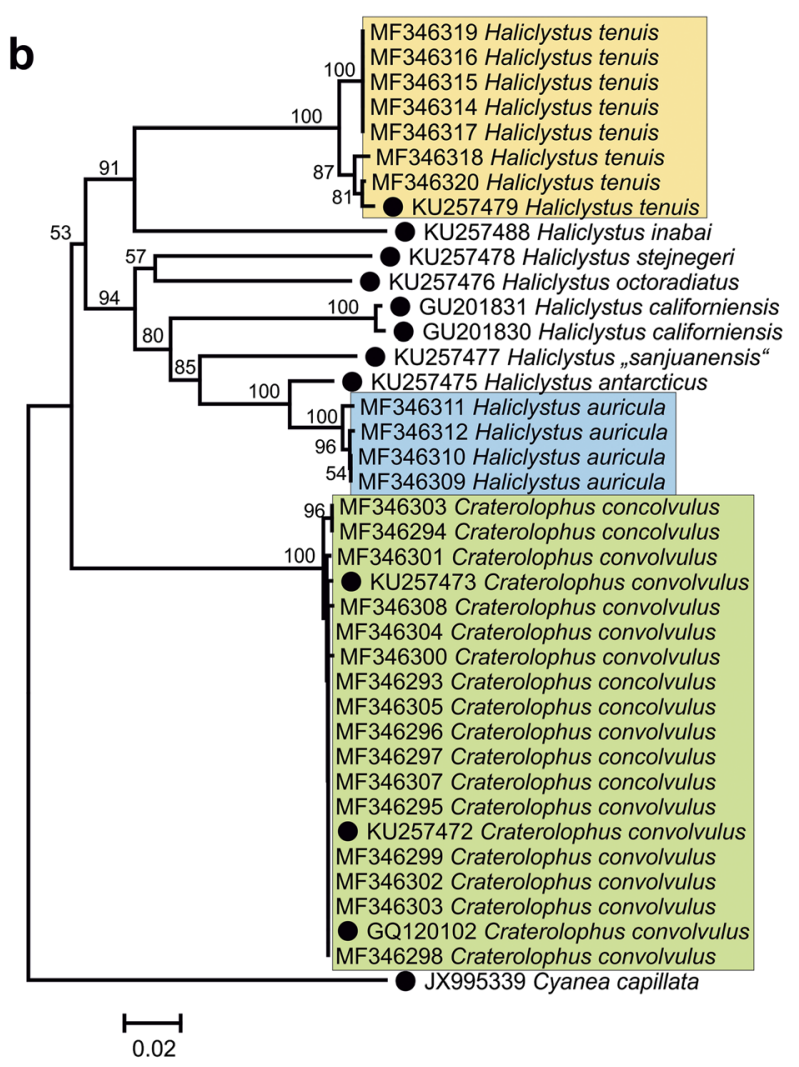

GenBank are indicated by black dots. a 595-bp fragment of mitochondrial 16S; b 648 bp of mitochondrial COI fragment; c 1721-bp fragment of nuclear $18 \mathrm{~S}$ rDNA

The NJ and ML analyses of COI reflected the same clear species differentiation of our specimens from Helgoland as the $16 \mathrm{~S}$ analyses with high bootstrap support for all three species clusters $(100 \%$ in NJ, $98 \%$ and $99 \%$ in ML, Fig. 6b, Online Resource 4b). Craterolophus convolvulus, $H$. auricula, and $H$. tenuis differed by $18.83-20.06 \%$ while specimens of the same species differed by $0-2.16 \%$, resulting in a pronounced barcoding gap of $16.67 \%$. Similar to the 


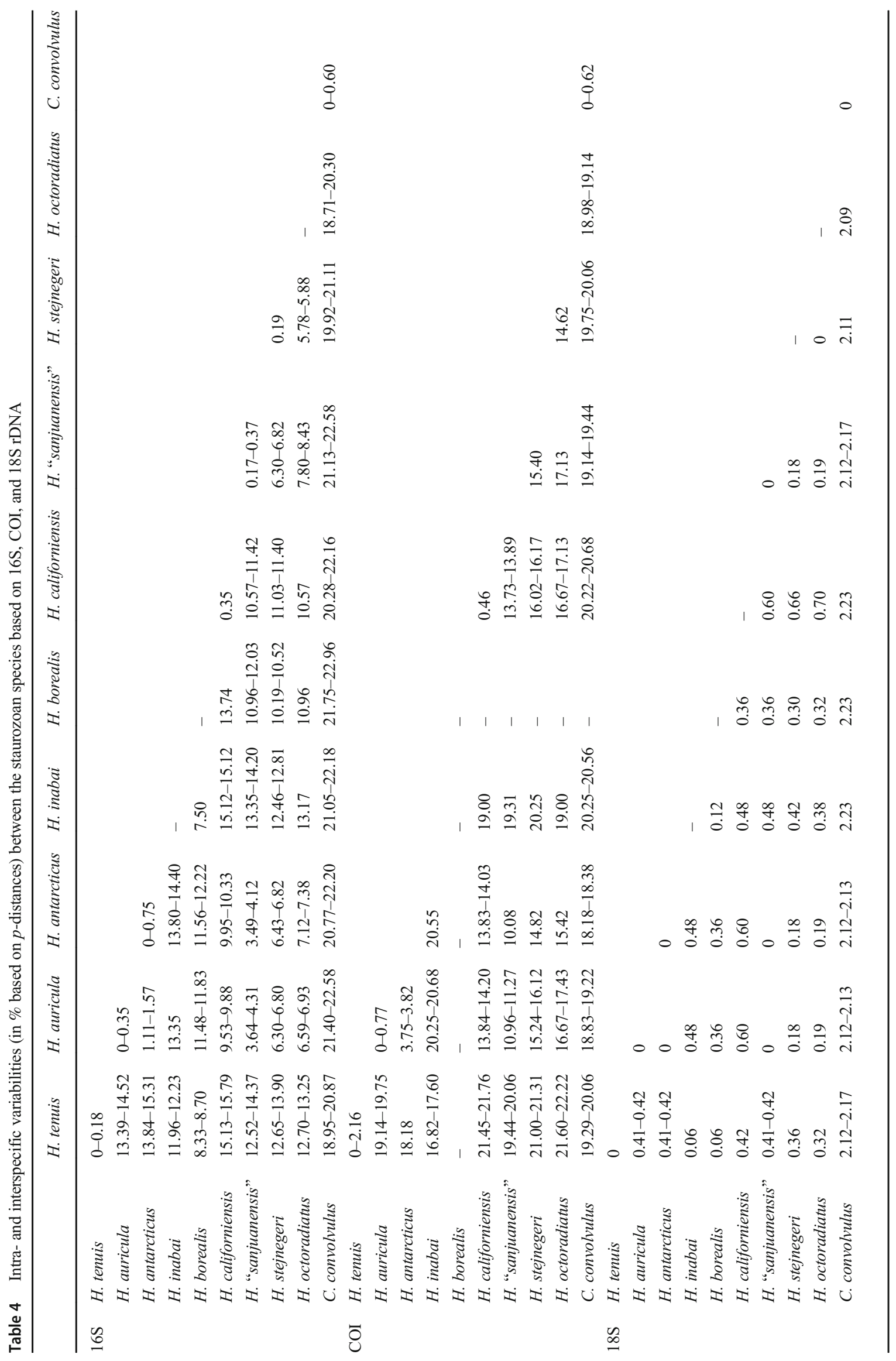


results of the $16 \mathrm{~S}$ analysis, the overall barcoding gap for staurozoans including GenBank sequences was very small $(1.59 \%)$, as a result of the highest intraspecific variability in H. tenuis $(2.16 \%)$ and the lowest interspecific variability between $H$. auricula from Helgoland and $H$. antarcticus from King George Island, Antarctic Peninsula (KU257475, Miranda et al. 2016b) (3.75\%). Considering H. auricula and $H$. antarcticus specimens as one species cluster, the barcoding gap of all analyzed staurozoan species would be $6.26 \%$ between the intraspecific $(0-3.82 \%)$ and the interspecific (10.08-22.22\%) variabilities (Table 4). The two species form a clade, supported by $100 \%$ (NJ) and $94 \%$ (ML) bootstrap support (Fig. 6b, Online Resource 4b). Craterolophus convolvulus from our study clustered together with specimens from Helgoland (KU257472, Miranda et al. 2016b), Cornwall, England, UK (KU257473, Miranda et al. 2016b), and another specimen without given sampling location (GQ120102, Ortman et al. 2010). Intraspecific variability in this species was $0-0.62 \%$. Haliclystus tenuis again clustered with $H$. tenuis from Hokkaido, Japan (KU257479, Miranda et al. 2016b), with intraspecific variability ranging from 0 to $2.16 \%$. Two clusters were supported, differing by $1.54-2.16 \%$ with the first one comprising five Helgoland specimens and the second cluster comprising two specimens from Helgoland and one from Japan (Fig. 6b, Online Resource 4b).

Even though the NJ and ML analyses of 18S rDNA separated the three species collected on Helgoland, the analysis did not clearly separate all different Haliclystus species, when GenBank sequences were included in our analysis (Fig. 6c, Online Resource 4c). While no intraspecific variability was observed, Haliclystus species differed from one another by $0-0.70 \%$ and from C. convolvulus by $2.09-2.23 \%$ (Table 4 ). Again, C. convolvulus clustered together with a specimen from Helgoland (AY845344, Collins and Daly 2005) and $H$. tenuis with the specimen from Hokkaido, Japan (KU308564, Miranda et al. 2016b), supported by 100\% (NJ) and $85 \%$ (ML). Haliclystus auricula clustered together not only with $H$. antarcticus specimens from Chile (AY845348, Collins and Daly 2005) and the Antarctic Peninsula (EU247811; declared as Microhydrula limopsicola, Collins et al. 2008) but also with the species Haliclystus "sanjuanensis" from unspecified location (AF358102, Collins 2002) and San Juan Island, Washington, USA (KU308562, Miranda et al. 2016b), supported by a bootstrap value of $95 \%$ (NJ, Fig. 6c) and $77 \%$ (ML, Online Resource 4c). Also, the specimens of Haliclystus stejnegeri Kishinouye, 1899 from Hokkaido, Japan (KU308563, Miranda et al. 2016b), and Haliclystus octoradiatus Clark, 1863 from Cornwall, England (KU308561, Miranda et al. 2016b), could not be separated based on NJ and ML analyses of the 18S rDNA gene fragment.

\section{Proteomic fingerprinting}

All three species showed species-specific proteomic fingerprints, resulting in a clear differentiation of the three species with high bootstrap values (Fig. 7). The support of the different species clusters of $C$. convolvulus, $H$. tenuis, and H. auricula was similar for all three analyses with bootstrap values of $75 \%, 97 \%$, and $92 \%$ based on the matrix with absolute values, $97 \%, 100 \%$, and $100 \%$ based on the matrix with relative intensities, and $68 \%, 100 \%$, and $100 \%$ based on the binary matrix (Fig. 7). The closer relationship of the two Haliclystus species was shown by high bootstrap values of $71-88 \%$ in all three analyses. Within C. convolvulus, in both the analyses of relative intensities and the binary matrix, different intraspecific clusters were shown comprising $\mathrm{Cc} 4$, $\mathrm{Cc} 15, \mathrm{Cc} 16$, and $\mathrm{Cc17}$ (97\% and 68\% bootstrap support); $\mathrm{Cc} 12, \mathrm{Cc} 13$, and $\mathrm{Cc} 14$ (98\% and $92 \%$ bootstrap support); and $\mathrm{Cc} 1, \mathrm{Cc} 2, \mathrm{Cc} 3, \mathrm{Cc} 5$, and $\mathrm{Cc} 6(78 \%$ and $90 \%$ bootstrap support). Furthermore, the togetherness of the latter two clusters was supported by $96 \%$ and $90 \%$ bootstrap support.

\section{Discussion}

\section{Macromorphological differences between staurozoan species from Helgoland}

The staurozoan species collected on Helgoland were distinguishable by their macromorphological characteristics. C. convolvulus, is classified to the family Craterolphidae (suborder Amyostaurida) (Miranda et al. 2016b). The genus Craterolophus Clark, 1863 comprises only two valid species: Craterolophus macrocystis von Lendenfeld, 1884 recorded from the coast of New Zeeland but not recorded again since its original description and C. convolvulus recorded from several localities in Europe and the northern coast of the USA (Miranda et al. 2018). Regarding the morphological features investigated in our study, C. convolvulus mainly differed from Haliclystus species in the short peduncle (stalk/calyx length ratios $<0.5$ ), the absence of anchors, and the shape of the gonads which were organized in pockets arranged in a featherlike shape and not in vesicles as in Haliclystus species (Fig. 2). These morphological features of C. convolvulus were in accordance with previous descriptions of the species which show that the particular shape of the gonads is characteristic for Craterolophus spp. (e.g., Clark 1863 as Craterolophus tethys; Mayer 1910 as C. tethys; Kramp 1961). Gonads of stauromedusae are generally organized in vesicles as evaginations of gastrodermis, but in some species, the gonadal content is restricted to a simple layer between gastrodermis and epidermis, without the organization of vesicles (Miranda et al. 2016a). 

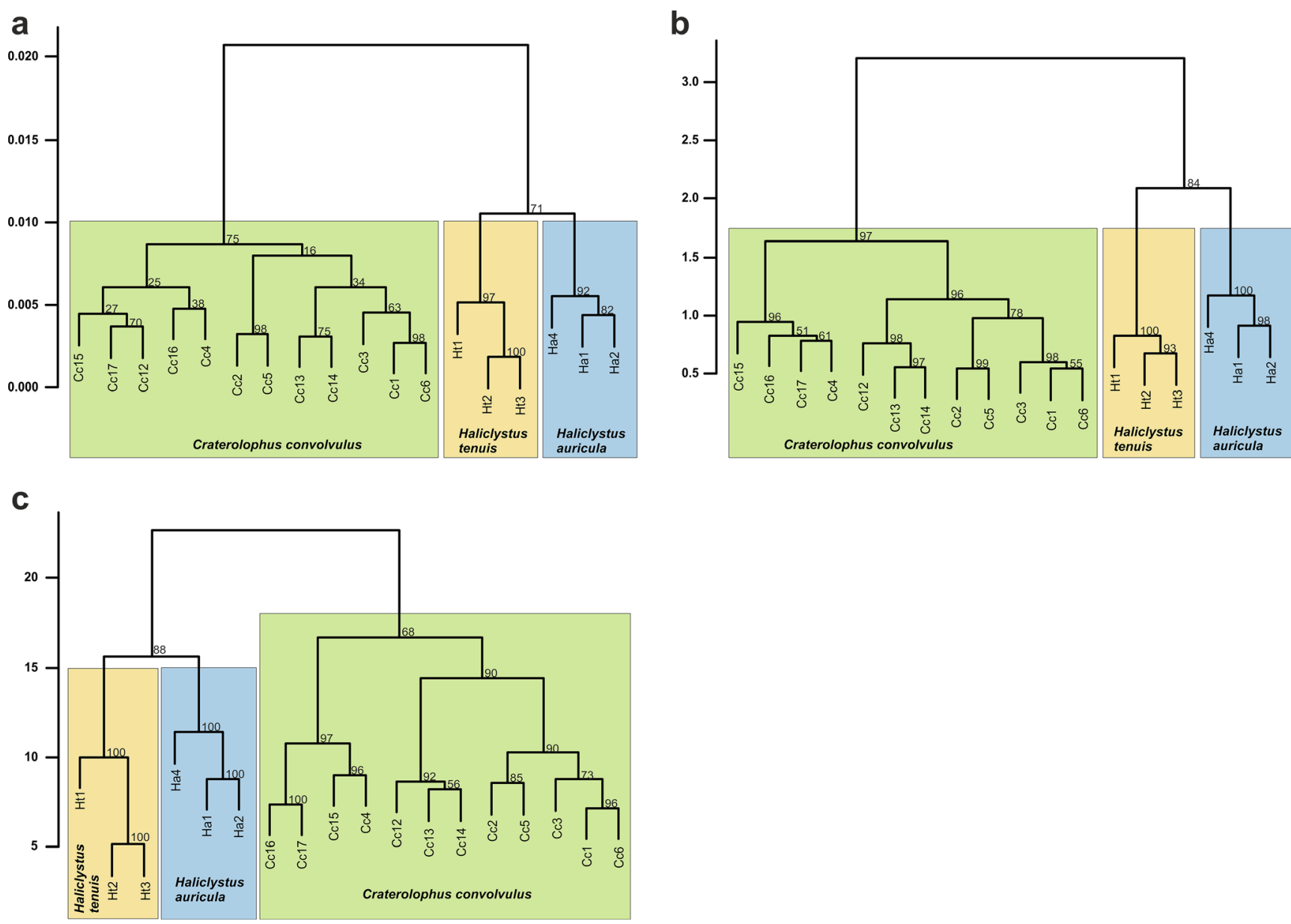

Fig. 7 Proteomic fingerprinting for the species Haliclystus tenuis, Haliclystus auricula, and Craterolophus convolvulus. Cluster analyses of a absolute values; $\mathbf{b}$ relative intensities; and $\mathbf{c}$ binary matrix. Numbers on branches are bootstrap values

The appearance of anchors is restricted to the Haliclystidae (suborder Myostaurida) (Miranda et al. 2016a, b) and is a reliable feature to identify the family. The genus Haliclystus currently comprises 13 species (Miranda et al. 2018), distinguishable by morphological features including the anchor shape, the number of tentacles per cluster, the number of gonad vesicles, stalk and calyx dimensions, the location of white spots of nematocysts, and the structure of the internal tentacle base (Miranda et al. 2009; Kahn et al. 2010). We confirmed differences in the shape of anchors between $H$. tenuis and $H$. auricula, indicating that the slightly wider than long anchor shape seems to be distinctive for $H$. tenuis (Hirano 1997). However, the taxonomic value of the shape of the anchors has to be regarded with caution because of probable ontogenetic variation (Miranda et al. 2009, 2016b). Counts on secondary tentacles and gonad follicles confirmed that these features show interspecific differences but also overlaps and high intraspecific variability, and thus, the taxonomic value of these features is limited (Hirano 1986, 1997; Miranda et al. 2009). Within the genus Haliclystus, the absence of white nematocyst spots is a diagnostic identification feature for $H$. auricula and $H$. antarcticus (Miranda et al.
2009, 2013). For H. tenuis and C. convolvulus, our results revealed a similar pattern of white nematocyst spots at the interradial and perradial subumbrella margin and along the perradial subumbrella between the gonads. However, within the genus Haliclystus, this pattern of white spots is characteristic for H. tenuis (Hirano 1997; Miranda et al. 2009). Haliclystus inabai (Kishinouye, 1893), has a similar pattern of white spots but differs from $H$. tenuis due to its conspicuously slender calyx with wide perradial and narrow interradial clefts (Hirano 1986 as Stenoscyphus inabai). The specific pattern of white spots combined with the characteristic connecting structure at the internal tentacle base led to the morphologically based identification and the first record of $H$. tenuis in the North Sea (Holst and Laakmann 2019). Comparative studies on the internal anatomy of Staurozoa (Miranda et al. 2016a) revealed that the intertentacular lobules at the base of the tentacles, confirmed for $H$. auricula and $C$. convolvulus by present investigations, are internal projections between adjacent secondary tentacles. Histological studies on nine staurozoan species (five genera, four families) (Miranda et al. 2016a), including H. tenuis and C. convolvulus, indicated that intertentacular lobules are 
widespread in Staurozoa and their presence is a probable synapomorphy for the class, whereas the connecting structure at the internal tentacle base (termed as "U-shaped" space in earlier studies, e.g., Hirano 1997; Miranda et al. 2009, 2013) may be restricted to some species of the genus Haliclystus. Confirming previous studies (Miranda et al. 2009, 2016a), our results demonstrate that histological sections are not necessarily required for the identification of these internal arm structures. Instead, the investigation of this taxonomic important feature is practicable by simple cuts through the arms of ethanol- or formalin-preserved specimens. Formalin preservation is more suitable for preservation purposes since the ethanol-preserved tissues tend to disintegrate during the preparation and the specimens are much contracted (present results). Thus, preparation of ethanol-preserved material is more difficult and can cause more severe damage of the specimens. We therefore suggest using different preservations to enable a broad range of analyses.

Certain morphological features (shape, size, color) are lost during preservation, comparable with the observations on soft-bodied hexacorals (Häussermann 2004). For this reason, a detailed photo documentation of the living specimens is recommended. Our measurements on stalk and calyx lengths documented similar stalk/calyx ratios in H. tenuis $(0.8 \pm 0.0)$ and $H$. auricula $(0.9 \pm 0.3)$, reflecting a slightly smaller stalk than calyx length in both species. This result confirms previous descriptions on similar peduncle and calyx lengths in H. auricula (Miranda et al. 2009; Kahn et al. 2010). However, our results were not in accordance with previous studies on $H$. tenuis describing a short peduncle of about half the length of the calyx (Kishinouye 1910; Miranda et al. 2009; Kahn et al. 2010). It is likely that the interspecific variability of body dimensions in staurozoans is high. Nevertheless, our results demonstrate that morphometric measurements on photographs can provide important taxonomic data. The calculated ratios of body proportions provide verifiable data and a better intraspecific and interspecific comparability, whereas descriptions in words (e.g., Miranda et al. 2009; Kahn et al. 2010) are less objective.

\section{Interspecific differences of nematocysts}

The nematocyst analysis of the three staurozoans is (to our knowledge) the first study on staurozoans targeting measurements on at least 40 capsules of each type per tissue and thereby meeting the guidelines for nematocyst analyses suggested for soft-bodied hexacorals (Häussermann 2004). We confirmed the appearance of two categories of nematocysts, isorhizas, and rhopaloids, as previously described for staurozoan species (e.g., Fautin 2009; Miranda et al. 2009). However, we revealed interspecific differences in isorhiza shapes and three types of rhopaloids with statistically different $1 / \mathrm{w}$ ratios. Interspecific differences in isorhiza shapes were previously documented for the species Calvadosia capensis (Carlgren, 1938), and Calvadosia campanulata (Lamouroux, 1815). Interspecific abundances of nematocyst types in different body regions were documented among the species H. antarcticus and H. octoradiatus (Carlgren 1930). Our photographs on discharged nematocysts indicate the appearance of one eurytele and two types of birhopaloids (Fig. 5n-p); however, this result should be regarded as preliminary since the use of fresh tissues is indispensable for a correct identification of capsule types (Heins et al. 2015). Roundish rhopaloids were present in $H$. tenuis and $C$. convolvulus and appeared in high abundances in the white spots but were not present in any body part of $H$. auricula specimens which lacked white spots. Roundish rhopaloids in the white spots were also documented for other staurozoans (Miranda et al. 2012b, 2017), and it is likely that roundish rhopaloids are only present in species with white nematocyst spots. Some studies indicate that the white nematocyst spots can also contain oval rhopaloids (e.g., Larson 1988; Miranda et al. 2012b). Histological sections on various staurozoan species revealed a region of nematocyst formation at the peripheral region of white spots (Miranda et al. 2016a). Thus, it can be difficult to isolate nematocysts from the white spots without contamination from the peripheral region of nematocyst formation which could lead to confusions in the identification of nematocyst from the white spots. As previously shown for several staurozoan species (e.g., Larson 1980, 1988; Kahn et al. 2010; Zagal et al. 2011), smaller rhopaloids compared to those in other body regions were documented in the gastric filaments of the species investigated in our study, indicating that these small rhopaloids are probably a special nematocyst type that may play a role in the digestion of captured prey.

Summarizing the species-specific differences detected among the nematocysts of the examined species, we documented that (1) the capsule shape ( $1 / \mathrm{w}$ ratio) of $H$. auricula isorhizas differed significantly to the isorhiza shape in the other two species, (2) the roundish rhopaloid type 2 was not present in any of the examined body parts of $H$. auricula, and (3) the type 1 rhopaloids in the anchors of $H$. tenuis were significantly larger than those in the anchors of $H$. auricula. These results indicate that cnidome analyses including capsule morphometrics may provide a useful taxonomic tool (Miranda et al. 2009). However, the available data on staurozoan cnidomes are too limited to verify the taxonomic value of this feature. Moreover, nematocyst analyses are rather unsuitable as a diagnostic feature for the routine method for species identification because of high intraspecific variations and the extremely time-consuming procedure.

\section{Molecular species differentiation}

Molecular species differentiation of the three analyzed staurozoan species from Helgoland was successful, for 
both DNA sequence analyses and proteomic fingerprinting. Low intraspecific variabilities in mitochondrial COI and $16 \mathrm{~S}$ clearly identified C. convolvulus specimens collected on Helgoland as the same species as the specimens recorded from the same and other localities in the Northeast and Northwest Atlantic (Collins and Daly 2005; Ortman et al. 2010; Miranda et al. 2016b).

Considering all sequences for Haliclystus species included in our analyses from GenBank, the difference between the intra- and interspecific variabilities in mitochondrial gene fragments (i.e., barcoding gap) was very low as a result of the small interspecific variability between $H$. auricula and H. antarcticus. However, if the two species would be regarded as one species cluster, the resulting barcoding gap of COI (6.26\%) would be comparable to the values of other cnidarian groups like hydrozoans (e.g., 5.4\% in Laakmann and Holst 2014). The intra- and interspecific variabilities for the genus Haliclystus provided in previous studies were based on lower species numbers compared to our study. For $16 \mathrm{~S}$, we yielded similar results for intraspecific variability $(0-0.75 \%)$ as Miranda et al. (2010) (0.19-0.77\%). However, the lowest interspecific variability in previous studies was higher (4.02\%) (Collins and Daly 2005) compared to our results (1.11\%), due to the small interspecific variability between $H$. auricula and $H$. antarcticus. For $18 \mathrm{~S}$ rDNA gene fragments, the interspecific variability among Haliclystus species in our analyses $(0$ $0.6 \%$ ) was similar to published data $(0.5 \%$ in Collins and Daly 2005). As a result, the mitochondrial markers (COI, 16S) worked well for species differentiation of staurozoan species as previously demonstrated for this taxon (Collins and Daly 2005; Miranda et al. 2016b; Holst and Laakmann 2019) as well as for other cnidarian taxa (e.g., Dawson 2005; Moura et al. 2008; Ortman et al. 2010; Laakmann and Holst 2014). These studies demonstrate a clearer separation of the species by $\mathrm{COI}$ analyses than by $16 \mathrm{~S}$ analyses, due to greater genetic variability. The analysis of $18 \mathrm{~S}$ rDNA does not resolve on species level in the genus Haliclystus, and the observed small differences in $18 \mathrm{~S}$ rDNA among congeners were also shown for other cnidarian groups (e.g., in Scyphozoa, Holst and Laakmann 2014).

The proteomic fingerprinting approach clearly separated the different species and thus proved as appropriate species identification and differentiation method for Staurozoa as already demonstrated for other metazoans (e.g., Volta et al. 2012; Salla and Murray 2013; Laakmann et al. 2013; Bode et al. 2017; Kaiser et al. 2018). The similarity of our molecular results underlines the applicability of both methods for valid species differentiation and identification. Our data demonstrate that differentiation between $H$. tenuis and $H$. auricula was possible by proteomic fingerprinting, revealing that the method provides the potential to distinguish staurozoan congeners. The advantage of proteomic fingerprinting using the MALDI-TOF MS approach compared to molecular genetic analysis on single individuals is the few preparation steps (i.e., extraction, preparation of target plate for the analysis) and the need for few consumables for the analysis. Thus, the fast and inexpensive sample preparation and sample analysis (within minutes) allow for cost- and time-effective application to analyze large sample sizes, e.g., for monitoring studies. However, additional data on other staurozoan species should be recorded to confirm the suitability of the method for a reliable species differentiation in Staurozoa. In addition, a reliable reference database for staurozoans and other metazoans must be established before this method can be used as a routine method for species identification (Bode et al. 2017).

\section{Morphological and molecular distinction of investigated Haliclystus species from similar congeners}

Our results demonstrate challenges in both morphological species discrimination and species allocation based on currently available molecular genetic sequence data of Haliclystus species from Helgoland. Our analyses indicate that $H$. auricula is very similar to $H$. antarcticus. If these two species would be regarded as conspecific, they would have the highest intraspecific variability among Haliclystus species which could be explained by the great geographic distance between the sampling locations on the Northern and Southern Hemisphere. Furthermore, the clear barcoding gap in both mitochondrial gene fragments would allow a clear species differentiation in the genus Haliclystus, more pronounced in COI than in 16S. Previous studies have already pointed out the morphological similarity of $H$. auricula and $H$. antarcticus, concerning the absence of white nematocyst spots and the internal arm structure with lobules at the tentacle bases (Miranda et al. 2009, 2013). Nevertheless, it is assumed that the distribution of $H$. antarcticus is restricted to the Southern Hemisphere whereas H. auricula occurs in the Northern Hemisphere (Miranda et al. 2009, 2018; Kahn et al. 2010). The proportions of stalk length and calyx height and of stalk width and anchor height were presumed as distinct morphological differences between $H$. auricula and H. antarcticus (Miranda et al. 2009). Our morphometric measurements confirmed that the stalk of $H$. auricula is nearly as long as the calyx height, whereas the stalk was described as only half to two thirds long as the calyx height in H. antarcticus (Pfeffer 1889; Miranda et al. 2009). However, we could not confirm that the height of the anchors in $H$. auricula is only one third to one fourth of the stalk width as previously described for the species (Miranda et al. 2009). Instead, the height of the anchors was about half of the diameter of the stalk in our specimens (stalk width/anchor height ratio $2.1 \pm 0.2$ ). This stalk/anchor proportion is similar to previous descriptions on $H$. antarcticus, documenting that the anchors of the species are half to two thirds as wide as the 
diameter of the stalk (Miranda et al. 2009). Measurements on $H$. antarcticus (Miranda et al. 2009) were made on preserved material while the measurements in our study were made on photographs of living material. The two different methods may lead to different results because formalin preservation can cause significant shrinkage of soft tissues as for example shown for scyphozoans (Holst and Laakmann 2014), and an even stronger contraction was documented for ethanolpreserved staurozoans (Holst et al. 2016). Moreover, it is likely that stalk/calyx and stalk/anchor proportions show intraspecific and ontogenetic variations as previously documented for several characteristics of Staurozoa (Miranda et al. 2009). The measurement data of the calyx, anchors, and stalk of Haliclystus specimens from Chile and Argentina, identified as H. auricula by Zagal (2004a, b, 2008) and Amor (1962), were similar to the measurements on $H$. antarcticus later recorded from the same and additional localities (Miranda et al. 2009). It was therefore suggested that the specimens were misidentified by Zagal (2004a, b, 2008) and Amor (1962), and that their true identity is $H$. antarcticus (Miranda et al. 2009). Future integrated taxonomic studies on $H$. auricula and $H$. antarcticus including more comprehensive sequence data (i.e., high sample sizes from wide distribution ranges and analyses of additional gene fragments) in combination with morphological analyses of diagnostic characters will elucidate the taxonomic status of the two species and will reveal whether the two species are closely related and difficult to differentiate, or whether $H$. auricula is conspecific with $H$. antarcticus and has a wide distribution range. If future studies would confirm that $H$. auricula and $H$. antarcticus can be regarded as the same species, the differences in stalk/calyx and stalk/ anchor proportions (Miranda et al. 2009; present study) would represent intraspecific variations. Haliclystus auricula is the type species of the genus Haliclystus, and the species name Haliclystus auricula Clark, 1863 would have priority over Haliclystus antarcticus Pfeffer, 1889 if regarded as synonyms.

The appearance of nematocyst types in different body regions of $H$. auricula (present study) was similar to that of $H$. antarcticus (Miranda et al. 2009), supporting the possibility that they represent the same species. The isorhizas of $H$. antarcticus had a $1 / w$ ratio of 3.1 (calculated from mean values given in Miranda et al. 2009) resembling the characteristic stout shape of isorhizas in $H$. auricula. The heterotrichous nematocysts described for $H$. antarcticus (Miranda et al. 2009) correspond to the nematocyst type termed as rhopaloids (after Östman 2000) in our study. This type appeared in significant smaller sizes in the gastric filaments than in other investigated body regions in H. antarcticus (Miranda et al. 2009) comparable to the type 3 rhopaloid in the gastric filaments of $H$. auricula (present study). In accordance with $H$. auricula (present results), roundish rhopaloids (type 2) were not documented for any investigated tissue in H. antarcticus (Miranda et al. 2009).
The nematocyst types documented for $H$. auricula had similar size ranges as documented for $H$. antarcticus (Miranda et al. 2009) but appeared in larger mean sizes in the latter probably because larger specimens were used for the nematocyst analyses. The calyx width range was larger (4.1-23.4 mm) in the investigated $H$. antarcticus specimens (Miranda et al. 2009) than in investigated H. auricula specimens $(5.7-10.6 \mathrm{~mm})$ (Table 2). Increasing medusa sizes are correlated to increasing nematocyst sizes in cubozoans and scyphozoans (Carrette et al. 2002; Jarms et al. 2002; Heins et al. 2015), and it is likely that this is also true for staurozoans. In addition, the appearance of nematocyst types can vary between developmental stages in the life cycle of scyphozoans (Calder 1983; Holst et al. 2007; Heins et al. 2015). In conclusion, the value of nematocyst analyses for species differentiation is limited and it is important to consider the size and developmental stage for interspecific comparisons.

In earlier studies, $H$. auricula was supposed to be a morphologically variable, circumpolar distributed species regarded as conspecific with $H$. octoradiatus from North Atlantic waters as well as with $H$. tenuis and $H$. "sanjuanensis" from North Pacific waters (Kramp 1961; Hirano 1986). These species were regarded as synonyms because of the overlap of known morphological characters as the number of gonadal follicles (Hirano 1997). However, Hirano (1997) revealed the morphological differentiation of the species based on the location of white spots of nematocysts on the subumbrella and the morphology of the base of the tentacle clusters. Based on these results, later studies regarded H. auricula, H. octoradiatus, H. tenuis, and $H$. "sanjuanensis" as distinct species (e.g., Miranda et al. 2009; Kahn et al. 2010). Further studies confirmed that white spots of nematocysts occur on the subumbrella in $H$. octoradiatus, H. tenuis, and $H$. "sanjuanensis" but are absent in $H$. auricula, and that the internal tentacle base of $H$. auricula, $H$. octoradiatus, and $H$. "sanjuanensis" is a shallow internal space with lobules whereas the internal tentacle base of $H$. tenuis is U-shaped without lobules (Miranda et al. 2016a; Holst and Laakmann 2019; present study). Previous molecular genetic data confirm that $H$. octoradiatus, $H$. tenuis, and $H$. "sanjuanensis" are distinct species (Miranda et al. 2016b; Holst and Laakmann 2019). By providing the first mitochondrial sequences (i.e., COI, 16S) for $H$. auricula from the Northern Hemisphere, we now confirmed that $H$. auricula is distinct from $H$. octoradiatus, $H$. tenuis, and $H$. "sanjuanensis." The analyses of all three gene fragments indicate a close relationship between the species $H$. auricula, $H$. antarcticus, and $H$. "sanjuanensis" as well as the species H. stejnegeri and $H$. octoradiatus, as already demonstrated by single-gene and multiple-gene analyses of mitochondrial and nuclear genes in previous studies (Miranda et al. 2010, 2016b). Moreover, complete mitogenome analyses with $90 \%$ identity demonstrate the close relationship of $H$. antarcticus and $H$. 
"sanjuanensis" (Li et al. 2016) and phylogenomic analyses of genome-scale data reveal the close relationship of $H$. auricula and H. "sanjuanensis" (Kayal et al. 2018). However, the presence of white nematocyst spots located perradially at the top of the gonads in H. "sanjuanensis" is morphologically distinct from $H$. auricula and $H$. antarcticus which lack white nematocyst spots (Hirano 1997; Miranda et al. 2009; present results). Haliclystus "sanjuanensis" shares morphological features with $H$. stejnegeri, both reported from the North Pacific (Kishinouye 1899; Hirano 1997; Miranda et al. 2009), but our molecular genetic analyses indicate that the latter is more closely related to $H$. octoradiatus from the North Atlantic in accordance with previous results on multigene analyses (Miranda et al. 2016b). The three species have a similar morphology with slight variations in the pattern of white nematocyst spots (Miranda et al. 2009) which may have led to morphological misidentifications (Miranda et al. 2018).

Haliclystus tenuis specimens sampled in Japan and the North Sea showed rather low intraspecific variability, probably indicating a non-native introduction (Holst and Laakmann 2019). The pattern of white spots of $H$. tenuis is similar to the Atlantic species $H$. octoradiatus, representing a risk of confusion of both species (Holst and Laakmann 2019). However, in contrast to $H$. tenuis, $H$. octoradiatus has intertentacular lobules at the internal base of the tentacles like H. auricula (Fig. 4) and the white spots are located close to the gonads in $H$. octoradiatus whereas they appear scattered between the gonads on the perradial subumbrella in $H$. tenuis (see figures in Hirano 1997; Faasse and Waajen 2011; Miranda et al. 2016a; Holst and Laakmann 2019). In contrast to our results, histological studies revealed the absence of nematocysts in the anchors of H. tenuis (Miranda et al. 2016a). Since anchors develop by metamorphosis of primary tentacles (Hirano 1986), it is likely that the appearance of nematocyst sizes in the anchors is dependent on the developmental stage and nematocysts may completely disappear in the advanced adult stage. The characteristic internal connecting structure at the tentacle bases of H. tenuis also appears in Haliclystus borealis Uchida, 1933 and Haliclystus californiensis Kahn et al., 2010 (Hirano 1986, 1997; Miranda et al. 2016a), but these species differ from H. tenuis in the shape of the anchors and the pattern of white nematocyst spots appearing at the subumbrella margin but not in the perradii (Hirano 1986; Miranda et al. 2009; Kahn et al. 2010). Specimens of $H$. borealis can usually be differentiated from $H$. tenuis and $H$. californiensis by their white stripes or flecks extending along the interradial exumbrella from the anchors to the base of the calyx; however, these stripes can lack in some individuals or fade out due to formalin preservation (Uchida 1933; Uchida and Hanaoka 1934; Hirano 1986). Our analyses of mitochondrial genes allow a clear separation of the three species while $18 \mathrm{~S}$ rDNA analysis indicates a closer relationship of $H$. tenuis and $H$. borealis and these two appear to be closely related to $H$. inabai, also indicated by multi-gene analyses (Miranda et al. 2016b). The latter three species were reported from adjacent localities in the Northwest Pacific whereas $H$. californiensis was reported from the Northeast Pacific (Kahn et al. 2010; Miranda et al. 2018).

\section{Conclusions for future taxonomic studies on staurozoans}

Our investigations on morphological and molecular diagnostic species characters of Staurozoa collected on Helgoland led to conclusions for future taxonomic studies: (1) Macromorphological characteristics provide useful indications for species identification in Staurozoa but have to be regarded with caution because they are often subject to high intraspecific variations. (2) A detailed photo-documentation of macromorphological features of living specimens and a selection of different preservation media are recommended to keep different options for morphological and molecular analyses open. (3) Morphometric measurements and calculated ratios of body proportions provide a better intra- and interspecific comparability than descriptions in words. (4) The taxonomic value of nematocyst analyses in Staurozoa is still questionable because of high intraspecific variations and the lack of sufficient comparable data. (5) Analyses of the mitochondrial markers COI and 16S allow species differentiation in Staurozoa. (6) Proteomic fingerprinting is applicable for species differentiation in staurozoans and could provide a fast and inexpensive alternative for future species identification on the basis of a reliable reference database.

Acknowledgements We thank Karen Jeskulke for her assistance in sampling and laboratory work. We gratefully appreciate the scientific guest research service provided by the Biological Institute Helgoland (BAH) of the Alfred Wegener Institute, Helmholtz Centre for Polar and Marine Research. We thank Thomas Glatzel (Carl von Ossietzky University of Oldenburg) for the collaboration. This is publication no. 6 of Senckenberg am Meer Proteome Laboratory and publication no. 59 of Senckenberg am Meer Metabarcoding and Molecular Laboratory.

Funding This study was funded by the Federal Ministry of Education and Research of Germany (BMBF Grant Nos. 03F0499A and 03F0664A) and the Land Niedersachsen.

\section{Compliance with ethical standards}

Conflict of interest The authors declare that they have no conflict of interest.

Ethical approval All applicable international, national, and/or institutional guidelines for the care and use of animals were followed.

Sampling and field studies All necessary permits for sampling and observational field studies have been obtained by the authors from the competent authorities and are mentioned in the acknowledgements, if applicable. The study is compliant with CBD and Nagoya protocols. 
Data availability Genetic sequence data generated in this study were deposited in GenBank with Accession Numbers MF322725MF322746 and MF346293-MF346312. For all three gene fragments (COI, 16S and 18S rDNA), the multiple alignments, NJ and ML trees are available in Ddryad digital repository (https://doi.org/10.5061/ dryad.5cr6008). Raw data on nematocyst measurements and proteomic mass spectra analyzed during the current study are available from the corresponding author on reasonable request.

\section{References}

Amor A (1962) Sobre Stauromedusae del litoral Patagonico. Notas Mus La Plata Zool 20:89-96

Berrill M (1962) The biology of three New England stauromedusae, with a description of a new species. Can J Zool 40:1249-1262

Bode M, Laakmann S, Kaiser P, Hagen W, Auel H, Cornils A (2017) Unravelling diversity of deep-sea copepods using integrated morphological and molecular techniques. J Plankton Res 39:600-617

Boos K, Buchholz C, Buchholz F, Gutow L (2004) Bericht über die Zusammensetzung des Helgoländer Makrozoobenthos im Vergleich historischer und aktueller QuellenKlassifizierungsvorschlag nach der WRRL und Empfehlungen zum Monitoring. Landesamt für Natur und Umwelt (LANU) des Landes Schleswig-Holstein; Projektendbericht

Bridge D, Cunningham CW, DeSalle R, Buss LW (1995) Class-level relationships in the phylum Cnidaria: molecular and morphological evidence. Mol Biol Evol 12:679-689

Calder DR (1983) Nematocysts of stages in the life cycle of Stomolophus meleagris, with keys to scyphistomae and ephyrae of some western Atlantic Scyphozoa. Can J Zool 61:1185-1192

Carlgren O (1930) Die Lucernariden. Furth Zool Res Swed Antarc Exp 1901-1903 2:1-18

Carlgren O (1938) Eine neue südafrikanische Lucernariidae, Lucernariopsis capensis. K Fysiogr Sällsk Lund Förh 8:1-6

Carrette T, Alderslade P, Seymour J (2002) Nematocyst ratio and prey in two Australian cubomedusans, Chironex fleckeri and Chiropsalmus sp. Toxicon 40:1547-1551

Cartwright P, Evans N, Dunn C, Marques A, Miglietta M, Schuchert P, Collins A (2008) Phylogenetics of Hydroidolina (Hydrozoa: Cnidaria). J Mar Biol Assoc UK 88:1663-1672

Clark HJ (1863) Prodromus of the history, structure, and physiology of the order Lucernariae. J Boston Soc Nat Hist 7:531-567

Collins AG (2002) Phylogeny of Medusozoa and the evolution of cnidarian life cycles. J Evol Biol 15:418-432

Collins AG, Daly M (2005) A new deepwater species of Stauromedusae, Lucernaria janetae (Cnidaria, Staurozoa, Lucernariidae), and a preliminary investigation of stauromedusan phylogeny based on nuclear and mitochondrial rDNA data. Biol Bull 208:221-230

Collins AG, Schuchert P, Marques AC, Jankowski T, Medina M, Schierwater B (2006) Medusozoan phylogeny and character evolution clarified by new large and small subunit rDNA data and an assessment of the utility of phylogenetic mixture models. Syst Biol 55:97-115

Collins AG, Bentlage B, Lindner A, Lindsay D, Haddock SHD, Jarms G, Norenburg JL, Jankowski T, Cartwright P (2008) Phylogenetics of Trachylina (Cnidaria: Hydrozoa) with new insights on the evolution of some problematical taxa. J Mar Biol Asso UK 88:1673-1685

Corbin PG (1979) The seasonal abundance of four species of Stauromedusae (Coelenterata: Scyphomedusae) at Plymouth. J Mar Biol Asso UK 59:385-391

Cunningham CW, Buss LW (1993) Molecular evidence for multiple episodes of paedomorphosis in the family Hydractiniidae. Biochem Syst Ecol 21:57-69
Dawson MN (2005) Cyanea capillata is not a cosmopolitan jellyfish: morphological and molecular evidence for $C$. annaskala and C. rosea (Scyphozoa: Semaeostomeae: Cyaneidae) in SouthEastern Australia. Invertebr Syst 19:361-370

Edgar RC (2004) MUSCLE: multiple sequence alignment with high accuracy and high throughput. Nucleic Acids Res 32:1792-1797

Faasse MA, Waajen S (2011) De steelkwallen van Nederland (Cnidaria: Staurozoa). Nederlandse Faunistische Mededelingen 35:61-67

Fautin DG (2009) Structural diversity, systematics, and evolution of cnidae. Toxicon 54:1054-1064

Felsenstein J (1985) Confidence limits on phylogenies: an approach using the bootstrap. Evolution 39:783-791

Feltens R, Görner R, Kalkhof S, Gröger-Arndt H, von Bergen M (2010) Discrimination of different species from the genus Drosophila by intact protein profiling using matrix-assisted laser desorption ionization mass spectrometry. EMC Evol Biol 10:95

Fenselau C, Demirev PA (2001) Characterization of intact microorganisms by MALDI mass spectrometry. Mass Spectrom Rev 20:57-171

Folmer OM, Black W, Hoen R, Lutz R, Vrijenhoek R (1994) DNA primers for amplification of mitochondrial cytochrome c oxidase subunit I from diverse metazoan invertebrates. Mol Mar Biol Biotechnol 3:294-299

Gibb S (2014) MALDIquantForeign: import/export routines for MALDIquant. R pack. ver. 0.9. http://CRAN.R-project.org/ package=MALDIquantForeign

Gibb S, Strimmer K (2012) MALDIquant: a versatile R package for the analysis of mass spectrometry data. Bioinformatics 28:2270-2271

Gomez Daglio L, Dawson MN (2017) Species richness of jellyfishes (Scyphozoa: Discomedusae) in the Tropical Eastern Pacific: missed taxa, molecules, and morphology match in a biodiversity hotspot. J Invertebr Syst 31:635-663

Gwilliam GF (1956) Studies on west coast Stauromedusae. Dissertation, University of California

Häussermann V (2004) Identification and taxonomy of soft-bodied hexacorals exemplified by Chilean sea anemones; including guidelines for sampling, preservation and examination. J Mar Biol Assoc UK 84:931-936

Heins A, Glatzel T, Holst S (2015) Revised descriptions of the nematocysts and the asexual reproduction modes of the scyphozoan jellyfish Cassiopea andromeda (Forskål, 1775). Zoomorphology 134: 351-366

Hirano YM (1986) Species of Stauromedusae from Hokkaido, with notes on their metamorphosis. J Fac Sci Hokkaido Univ 24:182-201

Hirano YM (1997) A review of a supposedly circumboreal species of stauromedusa, Haliclystus auricula (Rathke, 1806). In: den Hartog JC (ed) Proceedings of the 6th International Conference on Coelenterate Biology, Leiden, pp 247-252

Hoang DT, Chernomor O, von Haeseler A, Minh BQ, Vinh LS (2018) UFBoot2: improving the ultrafast bootstrap approximation. Mol Biol Evol 35:518-522

Holst S, Laakmann S (2014) Morphological and molecular discrimination of two closely related jellyfish species, Cyanea capillata and C. lamarckii (Cnidaria, Scyphozoa), from the Northeast Atlantic. J Plankton Res 36:48-63

Holst S, Laakmann S (2019) First record of the stalked jellyfish Haliclystus tenuis Kishinouye, 1910 (Cnidaria: Staurozoa) in Atlantic waters. Mar Biodivers. 49(2):1061-1066

Holst S, Sötje I, Tieman H, Jarms G (2007) Life cycle of the rhizostome jellyfish Rhizostoma octopus (L.) (Scyphozoa, Rhizostomae), with studies on cnidocysts and statoliths. Mar Biol 151:1695-1710

Holst S, Michalik P, Noske M, Krieger J, Sötje I (2016) Potential of X-ray micro-computed tomography for soft-bodied and gelatinous cnidarians with special emphasis on scyphozoan and cubozoan statoliths. J Plankton Res 38:1225-1242 
Jarms G, Tiemann H (1996) On a new hydropolyp without tentacles, Microhydrula limopsicola $\mathrm{n}$. sp., epibiotic on bivalve shells from the Antarctic. Sci Mar 60:109-115

Jarms G, Tiemann H, Båmstedt U (2002) Development and biology of Periphylla periphylla (Scyphozoa: Coronatae) in a Norwegian fjord. Mar Biol 141:647-657

Johnston G (1835) Illustrations in British zoology. London's Mag Nat Hist 8:59-61

Kahn AS, Matsumoto GI, Hirano YM, Collins AG (2010) Haliclystus californiensis, a "new" species of stauromedusa (Cnidaria: Staurozoa) from the Northeast Pacific, with a key to the species of Haliclystus. Zootaxa 2518:49-59

Kaiser P, Bode M, Cornils A, Hagen W, Martínez Arbizu P, Auel H, Laakmann S (2018) High-resolution community analysis of deepsea copepods using MALDI-TOF protein fingerprinting. Deep-Sea Res Part I 138:122-130

Kalyaanamoorthy S, Minh BQ, Wong TKF, von Haeseler A, Jermiin LS (2017) ModelFinder: fast model selection for accurate phylogenetic estimates. Nat Methods 14:587-589

Kaufmann C, Ziegler D, Schaffner F, Carpenter S, Pflüger V, Mathis A (2011) Evaluation of matrix assisted laser desorption/ionization time of flight mass spectrometry for characterization of Culicoides nubeculosus biting midges. Med Vet Entomol 25:32-38

Kayal E, Bentlage B, Pankey MS, Ohdera AH, Medina M, Plachetzki DC, Collins AG, Ryan JF (2018) Phylogenomics provides a robust topology of the major cnidarian lineages and insights on the origins of key organismal traits. BMC Evol Biol 18:68

Kearse M, Moir R, Wilson A, Stones-Havas S, Cheung M, Sturrock S, Buxton S, Cooper A, Markowitz S, Duran C, Thierer T, Ashton B, Mentjies P, Drummond A (2012) Geneious basic: an integrated and extendable desktop software platform for the organization and analysis of sequence data. Bioinformatics 28:1647-1649

Kikinger R, Salvini-Plawen L (1995) Development from polyp to stauromedusa in Stylocoronella (Cnidaria: Scyphozoa). J Mar Biol Assoc UK 75:899-912

Kishinouye K (1893) Mushi-kurage, Depastrum inabai n. sp. Zool Mag 5:416-419

Kishinouye K (1899) Contributions to the natural history of the Commander Islands. XIII. A new species of stalked medusae, Haliclystus stejnegeri. Proc U S Nat Mus 22:125-129

Kishinouye K (1910) Some medusa of Japanese waters. J Coll Sci 27:135

Kramp PL (1961) Synopsis of the medusae of the world. J Mar Biol Assoc UK 40:5-469

Laakmann S, Holst S (2014) Emphasizing the diversity of North Sea hydromedusae by combined morphological and molecular methods. J Plankton Res 36:64-76

Laakmann S, Gerdts G, Erler R, Knebelsberger T, Martinez Arbizu P, Raupach MJ (2013) Comparison of molecular species identification for North Sea calanoid copepods (Crustacea) using proteome fingerprints and DNA sequences. Mol Ecol Resour 13:862-876

Lamouroux JVF (1815) Mémoire sur la Lucernaire campanulée. Mém Mus Hist Nat II:460-473

Larson RJ (1980) A new stauromedusa, Kishinouyea corbini (Scyphozoa, Stauromedusae) from the tropical western Atlantic. B Mar Sci 30:102-107

Larson RJ (1988) Kyopoda lamberti gen. nov., sp. nov., an atypical stauromedusa (Scyphozoa, Cnidaria) from the eastern Pacific, representing a new family. Can J Zool 66:2301-2303

Larson RJ, Fautin DG (1989) Stauromedusae of the genus Manania (= Thaumatoscyphus) (Cnidaria, Scyphozoa) in the Northeast Pacific, including descriptions of new species Manania gwilliami and Manania handi. Can J Zool 67:1543-1549

Li HH, Sung PJ, Ho HC (2016) The complete mitochondrial genome of the Antarctic stalked jellyfish, Haliclystus antarcticus Pfeffer, 1889 (Staurozoa: Stauromedusae). Genom Data 8:113-114
Linnaeus C (1758) Systema Naturae per regna tria naturae, secundum classes, ordines, genera, species, cum characteribus, differentiis, synonymis, locis. Editio decima, reformata. Laurentius Salvius: Holmiae

Mayer AG (1910) Medusae of the world, Vol 3. Carnegie Institution, Washington

Mazzeo MF, de Giulio B, Guerriero G, Ciarcia G, Malorni A, Russo GL, Siciliano RA (2008) Fish authentication by MALDI-TOF mass spectrometry. J Agric Food Chem 56:11071-11076

Miranda LS, Marques AC (2016) Hidden impacts of the Samarco mining waste dam collapse to Brazilian marine fauna - an example from the staurozoans (Cnidaria). Biota Neotropica 16:e20160169

Miranda LS, Morandini AC, Marques AC (2009) Taxonomic review of Haliclystus antarcticus Pfeffer, 1889 (Stauromedusae, Staurozoa, Cnidaria), with remarks on the genus Haliclystus Clark, 1863. Polar Biol 32:1507-1519

Miranda LS, Collins AG, Marques AC (2010) Molecules clarify a cnidarian life cycle - the "hydrozoan" Microhydrula limopsicola is an early life stage of the staurozoan Haliclystus antarcticus. PLoS One $5: \mathrm{e} 10182$

Miranda LS, Morandini AC, Marques AC (2012a) Do Staurozoa bloom? A review of stauromedusan population biology. Hydrobiologia 690: $57-67$

Miranda LS, Haddad MA, Mills CE, Marques AC (2012b) Lucernariopsis capensis Carlgren, 1938 (Cnidaria, Staurozoa) in Brazil: first record outside its type locality in South Africa. Zootaxa 3158:60-64

Miranda LS, Collins AG, Marques AC (2013) Internal anatomy of Haliclystus antarcticus (Cnidaria, Staurozoa) with a discussion on histological features used in Staurozoan taxonomy. J Morphol 274: 1365-1383

Miranda LS, Collins AG, Hirano YM, Mills CE, Marques AC (2016a) Comparative internal anatomy of Staurozoa (Cnidaria), with functional and evolutionary inferences. PeerJ 4:e2594

Miranda LS, Hirano YM, Mills CE, Falconer A, Fenwick D, Marques AC, Collins AG (2016b) Systematics of stalked jellyfishes (Cnidaria: Staurozoa). PeerJ 4:e1951

Miranda LS, Branch GM, Collins AG, Hirano YM, Marques AC, Griffiths CL (2017) Stalked jellyfishes (Cnidaria: Staurozoa) of South Africa, with the description of Calvadosia lewisi sp. nov. Zootaxa 4227:369-389

Miranda LS, Mills CE, Hirano YM, Collins AG, Marques AC (2018) A review of the global diversity and natural history of stalked jellyfishes (Cnidaria, Staurozoa). Mar Biodiv. 48(4):1695-1714

Moura CJ, Harris DJ, Cunha MR, Rogers AD (2008) DNA barcoding reveals cryptic diversity in marine hydroids (Cnidaria, Hydrozoa) from coastal and deep-sea environments. Zool Scr 37:93-108

Nei M, Kumar S (2000) Molecular evolution and phylogenetics. Oxford University Press, New York

Nguyen L-T, Schmidt HA, von Haeseler A, Minh BQ (2015) IQ-TREE: a fast and effective stochastic algorithm for estimating maximum likelihood phylogenies. Mol Biol Evol 32:268-274

Oksanen J, Blanchet FG, Kindt R, Legendre P, Minchin PR, O'Hara RB, Simpson GL, Solymos M et al. (2015) Vegan: community ecology package. R package ver 2.3-0. http://CRAN.Rpoject.org/package= vegan

Ortman BD, Bucklin A, Pages F, Youngbluth M (2010) DNA barcoding the Medusozoa using mtCOI. Deep-Sea Res II 57:2148-2156

Östman C (2000) A guideline to nematocysts nomenclature and classification, and some notes on the systematic value of nematocysts. Sci Mar 64(Supl 1):31-46

Östman C, Hydman J (1997) Nematocyst analysis of Cyanea capillata and Cyanea lamarckii (Scyphozoa, Cnidaria). Sci Mar 61:313-344

Otto JJ (1976) Early development and planula movement in Haliclystus (Scyphozoa: Stauromedusae). In: Mackie GO (ed) Coelenterates ecology and behavior. Springer, New York, pp 319-329 
Pfeffer G (1889) Zur Fauna von Süd-Georgien. Jahrb Hamburg Wiss Anst 6:37-55

Purcell JE, Mills CE (1988) The correlation between nematocysts types and diets in pelagic Hydrozoa. In: Hessinger DA, Lenhoff HM (eds) The biology of nematocysts. Academic Press, Orlando, pp 463-485

R Core Team (2015) R: A language and environment for statistical computing. R Foundation for Statistical Computing, Vienna, Austria. Available online at https://www.R-project.org/. Accessed 2 March 2017

Raupach MJ, Mayer C, Malyutina M, Wägele J-W (2009) Multiple origins of deep-sea Asellota (Crustacea: Isopoda) from shallow waters revealed by molecular data. Proc Royal Soc B 276:799-808

Reichert K, Buchholz F (2006) Changes in the macrozoobenthos of the intertidal zone at Helgoland (German Bight, North Sea): a survey of 1984 repeated in 2002. Helgol Mar Res 60:213-223

Riccardi N, Lucini L, Benagli C, Welker M, Wicht B, Tonolla M (2012) Potential of matrix-assisted laser desorption/ionization time-of-flight mass spectrometry (MALDI-TOF MS) for the identification of freshwater zooplankton: a pilot study with three Eudiaptomus (Copepoda: Diaptomidae) species. J Plankton Res 34:484- 492

Rothen J, Githaka N, Kanduma EG, Olds C, Pflüger V, Mwaura S, Bishop RP, Daubenberger C (2016) Matrix-assisted laser desorption/ionization time of flight mass spectrometry for comprehensive indexing of East African ixodid tick species. Parasit Vectors 9:151. https://doi.org/10.1186/s13071-016-1424-6

Saitou N, Nei M (1987) The neighbor-joining method: a new method for reconstructing phylogenetic trees. Mol Biol Evol 4:406-425

Salla V, Murray KK (2013) Matrix-assisted laser desorption ionization mass spectrometry for identification of shrimp. Anal Chim Acta 794:55-59

Simon C, Frati F, Beckenbach A, Crespi B, Liu H, Flook P (1994) Evolution, weighting, and phylogenetic utility of mitochondrial gene sequences and a compilation of conserved PCR primers. Ann Entomol Soc Am 87:651-701

Suzuki R, Shimodaira H (2014) pvclust: hierarchical clustering with Pvalues via multiscale bootstrap resampling. $\mathrm{R}$ package. ver. $1.3-2$. http://CRAN.R-project.org/package=pvclust

Tamura K, Nei M (1993) Estimation of the number of nucleotide substitutions in the control region of mitochondrial DNA in humans and chimpanzees. Mol Biol Evol 10:512-526
Tamura K, Stecher G, Peterson D, Filipski A, Kumar S (2013) MEGA6: molecular evolutionary genetics analysis version 6.0. Mol Biol Evol 30:2725-2729

Uchida T (1933) Eine neue Becherqualle aus Hokkaido. Proc Imp Acad 9:450-452

Uchida T, Hanaoka K-I (1934) Anatomy of two stalked medusae with remarks on the distribution of the Stauromedusae in Japan. Journal of the Facultuy of Science Hokkaido Imperial University 2:211-239

Volta P, Riccardi N, Lauceri R, Tonolla M (2012) Discrimination of freshwater fish species by matrix-assisted laser desorption/ ionization-time of flight mass spectrometry (MALDI-TOF MS): a pilot study. J Limnol 71:164-169

von Lendenfeld R (1884) The Schyphomedusae of the Southern Hemisphere. P Linn Soc NSW 9:155-169

Wieser A, Schneider L, Jung J, Schubert S (2012) MALDI-TOF MS in microbiological diagnostics - identification of microorganisms and beyond (mini review). Appl Microbiol Biotechnol 93:965-974

Zagal CJ (2004a) Population biology and habitat of the stauromedusa Haliclystus auricula in Southern Chile. J Mar Biol Assoc UK 84: $331-336$

Zagal CJ (2004b) Diet of stauromedusa Haliclystus auricula from Southern Chile. J Mar Biol Assoc UK 84:337-340

Zagal CJ (2008) Morphological abnormalities in the stauromedusa Haliclystus auricula (Cnidaria) and their possible causes. J Mar Biol Assoc UK 88:259-262

Zagal CJ, Hirano YM, Mills CE, Edgar GJ, Barrett NS (2011) New records of Staurozoa from Australian coastal waters, with a description of a new species of Lucernariopsis Uchida, 1929 (Cnidaria, Staurozoa, Stauromedusae) and a key to Australian Stauromedusae. Mar Biol Res 7:651-666

Zettler ML, Beermann J, Dannheim J, Ebbe B, Grotjahn M, Günther CP, Gusky M, Kind B, Kröncke I, Kuhlenkamp R, Orendt C, Rachor E, Schanz A, Schröder A, Schüler L, Witt J (2018) An annotated checklist of macrozoobenthic species in German waters of the North and Baltic seas. Helgol Mar Res 72:5

Publisher's note Springer Nature remains neutral with regard to jurisdictional claims in published maps and institutional affiliations. 